\title{
Effect of tartrazine on gastric mucosa and the possible role of recovery with or without riboflavin in adult male albino rat
}

\section{Original Article}

Walaa M. Elwan and Marwa A. A. Ibrahim

Department of Histology and Cell Biology, Faculty of Medicine, Tanta University

\begin{abstract}
Background: Tartrazine is one of the azo dyes that are the most common artificial food colors widely used in many food products. Tartrazine is used in many developing countries without strict regulations.

Aim of the study: to investigate the effect of tartrazine on the gastric mucosa and to evaluate the possible role of recovery after its withdrawal with or without riboflavin in rat.

Materials and Methods: Twenty-four adult male albino rats were equally divided into 4 groups; Control, riboflavin, tartrazinetreated group (orally administered $200 \mathrm{mg} / \mathrm{kg}$ /day tartrazine for 60 days), tartrazine-recovery group (orally administered 200 $\mathrm{mg} / \mathrm{kg}$ /day tartrazine for 60 days then left without treatment for another 60 days) and tartrazine-recovery and riboflavin group (that were orally administered tartrazine for 60 days then stopped and followed with riboflavin for another 60 days). Glandular stomach specimens were processed for histological and immunohistochemical techniques.

Results: Tartrazine-treated group depicted variable degrees of mucosal lesions with significant decrease in its thickness. Parietal cells with vacuolated cytoplasm and irregular nuclei, and vacuolated chief cells with pyknotic nuclei were detected. Dilated congested blood vessels and aggregated mononuclear cells were observed. Ultrastructural examination showed parietal and chief cells with condensed nuclei and dilated rough endoplasmic reticulum. Tartrazine-recovery group showed almost intact gastric mucosa. Tartrazine-recovery with riboflavin group showed a near normal gastric mucosa. Both Ki67 and iNOS-immunohistochemical expression showed a statistically significant increase upon tartrazine administration coupling to a significant decrease in Periodic-Acid-Schiff expression. Tartrazine-recovery group still revealed significant differences in these parameters compared to the control, while tartrazine-recovery with riboflavin showed non-significant differences from the control.
\end{abstract}

Conclusion: Tartrazine affected the stomach and was alleviated by stopping it. Combined recovery along with riboflavin was more efficient on the recovery of gastric mucosa.

Received: 22 November 2018, Accepted: 16 January 2019

Key Words: iNOS, Ki67; riboflavin; stomach; tartrazine.

Corresponding Author: Marwa A. A. Ibrahim, MD, Department of Histology, Faculty of Medicine, Tanta University, 31527

Tanta, Egypt, Tel.: +20109918 6399, E-mail: maleox68@yahoo.com, marwa.ibrahim@med.tanta.edu.eg

ISSN: 1110-0559, Vol. 42, No. 2

\section{INTRODUCTION}

Food colorants constitute an essential part of our daily life as they impacts the taste and sweetness of food making it more attractive ${ }^{[1]}$. Several sorts of natural and synthetic dyes are being used, yet the synthetic ones are more stable and less expensive thus occupy an important place in different food industries ${ }^{[2]}$. Azo dyes are the most common synthetic food colorants that include the aromatic azo compounds such as tartrazine ${ }^{[3]}$.

Tartrazine (referred also as E102) is a water soluble lemon yellow azo dye derived from petroleum products. It is widely used in many food products such as soft drinks, flavored chips, cereals, cake mixes, soups, sauces, ice cream, jam, candy, chewing gum and others ${ }^{[4,5]}$. Because of its relatively low cost, tartrazine is used in many developing countries as a substitute for saffron in cooking ${ }^{[6]}$. Besides, tartrazine is also used in many non-food products such as soaps, cosmetics, shampoos as well as some drugs such as vitamins, antacids, antihistaminics and antibiotics ${ }^{[7]}$.

The World Health Organization (WHO) reported the acceptable daily intake (ADI) of tartrazine to be about 7.5 $\mathrm{mg} / \mathrm{kg}^{[8]}$. Because of its nitrous origin, tartrazine is reduced in the intestine to sulphanilic acid which is an aromatic amine with a potentially carcinogenic or mutagenic capability ${ }^{[9]}$.

In many developing countries, the uncontrolled and unsupervised use of food colorants during festivals was above the ADI, which in turn resulted in serious health hazards ${ }^{[10]}$ especially among the vulnerable groups including children that showed some behavioral changes such as irritability, restlessness, hyperactivity and sleep disorders ${ }^{[11,12]}$. Moreover, it was previously reported that 
tartrazine can induce asthma, angioedema and urticaria in some atopic patients ${ }^{[13]}$, in addition to its immunotoxic ${ }^{[14]}$, genotoxic and mutagenic hazards ${ }^{[15,16]}$.

Riboflavin (also known as vitamin B2) is a water soluble vitamin, it is one of the vitamin B complex that naturally exists in a variety of plant and animal sources such as meat, liver, dairy products, eggs, almonds and leafy vegetables in addition to its availability as a dietary supplement. Riboflavin has a vital role in cellular function and growth as well as many enzymatic processes ${ }^{[17]}$.

The health benefits of riboflavin are multitudinous, it is used for the management of many clinical conditions such as migraine ${ }^{[18]}$, depression ${ }^{[19]}$ and it is also important for the wellness of the eye ${ }^{[20]}$ and bone ${ }^{[21]}$. Moreover, experts have argued that riboflavin possesses a potent antioxidant ${ }^{[22]}$, antiinflammatory ${ }^{[23]}$, immune-modulatory ${ }^{[24]}$, cardioprotective ${ }^{[25]}$, hepatoprotective ${ }^{[26]}$, neuroprotective ${ }^{[27]}$ and antineoplastic effects $^{[28]}$. Nevertheless, riboflavin nutritional deficiency has been considered as an important risk factor for some diseases including cancer ${ }^{[29]}$.

Based on the previous data, the current study was designed to investigate the effect of tartrazine on the glandular gastric mucosa and to evaluate the possible role of a recovery period after its withdrawal with or without riboflavin in adult male albino rat employing different histological and immunohistochemical methods.

\section{MATERIAL AND METHODS}

Twenty-four adult male albino rats weighing 180-200 grams each were used in the current work. The animals were kept on a standard 12h-light/12h-dark cycle before the experiment and throughout the study period in clean properly ventilated cages with access to a balanced laboratory diet and water ad libitum. The animals were kept for 2 weeks prior to the experiment for acclimatization. The experiment was approved by the Local Ethical Committee of the Faculty of Medicine, Tanta University, Egypt.

The animals were randomly allocated into four equal groups:

Group I (Control group): Animals of this group were orally administered $1 \mathrm{ml}$ of distilled water daily for 60 days.

Group II (Riboflavin-treated group): Animals of this group were orally administered $1 \mathrm{ml}$ of distilled water daily for 60 days then stopped and they were then orally administered riboflavin at a dose of $100 \mathrm{mg} / \mathrm{kg}$ for another 60 days $^{[30]}$. Riboflavin was purchased from Sigma Aldrich Chemical Co (Cat \# 47861 Supelco, St. Louis, MO, USA).

Group III (tartrazine-treated group): Animals were orally administered tartrazine at a dose of $200 \mathrm{mg} / \mathrm{kg}$ in 1 $\mathrm{ml}$ of distilled water daily for 60 days $^{[31]}$. Tartrazine was purchased from Sigma Aldrich Chemical Co (Cat \# T0388 SIGMA, St. Louis, MO, USA).

Group IV (tartrazine-recovery group): Animals were orally administered tartrazine at a dose of $200 \mathrm{mg} / \mathrm{kg}$ in $1 \mathrm{ml}$ of distilled water daily for 60 days then were left without treatment for another 60 days.

Group V (tartrazine-recovery and riboflavin group): Animals were orally administered tartrazine at a dose of $200 \mathrm{mg} / \mathrm{kg}$ in $1 \mathrm{ml}$ of distilled water daily for 60 days then tartrazine was stopped and the animals were orally administered riboflavin for another 60 days.

At the end of the experiment, animals were fasted for 24 hours before being euthanized under intraperitoneal injection of pentobarbital $(40 \mathrm{mg} / \mathrm{kg})^{[32]}$. The stomachs were rapidly dissected out, washed twice with normal physiological saline and processed for light and transmission electron microscopy.

\section{For light microscopy examination}

Glandular stomach specimens were immersed in $10 \%$ neutral-buffered formalin, washed, dehydrated, cleared and embedded in paraffin. Sections of $5 \mu \mathrm{m}$ thickness were stained with hematoxylin\&eosin $(\mathrm{H} \& \mathrm{E})^{[33]}$ and Periodic Acid Schiff reagent (PAS) for detection of neutral mucopolysaccharide ${ }^{[34]}$.

\section{For immunohistochemical staining}

Glandular stomach sections of $5 \mu \mathrm{m}$ thickness were deparaffinized, rehydrated and washed with phosphatebuffered saline (PBS) then were incubated with 10\% normal goat serum in PBS. Sections were incubated overnight in a humid chamber at $4{ }^{\circ} \mathrm{C}$ with the primary antibodies; rabbit polyclonal antibody anti-Ki67 (ab15580, Abcam, Cambridge, Massachusetts, USA) and rabbit polyclonal anti-iNOS (ab15323; Abcam, Massachusetts, USA) then were incubated with biotinylated goat antirabbit $\operatorname{IgG}$ for $60 \mathrm{~min}$ at room temperature, thereafter with a streptavidin-biotin-horseradish peroxidase complex for another $60 \mathrm{~min}$. The immunoreactivity was visualized using 3,3'-diaminobenzidine (DAB) chromogen. The sections were counterstained with Mayer's hematoxylin. The negative control sections were performed by excluding the primary antibodies ${ }^{[35]}$. The positive controls for the antibodies were mouse spleen tissue and mouse colon tissue respectively.

\section{For transmission electron microscopy examination}

Glandular stomach specimens were cut into small pieces and fixed in $4 \%$ phosphate buffered glutaraldehyde (0.1 M, pH 7.3), post-fixed with $1 \%$ phosphate-buffered osmium tetroxide, and then dehydrated in ascending grades of ethanol. After being immersed in propylene oxide, the specimens were embedded in epoxy resin mixture. Semithin sections ( $1 \mu \mathrm{m}$ thick) were stained with $1 \%$ toluidine blue and examined by light microscope for proper orientation. Ultrathin sections $(80-90 \mathrm{~nm})$ were stained with uranyl acetate and lead citrate ${ }^{[36]}$. The sections were examined with JEOL-JEM-100 transmission electron microscope (Tokyo, Japan) at the Electron Microscopic Unit, Faculty of Medicine, Tanta University, Egypt. 


\section{Morphometric analysis}

A Leica light microscope (DM500, Swizterland) coupled to a Leica digital camera (ICC50, Swizterland) was used for image acquisition and the software "ImageJ" (version $1.48 \mathrm{v}$ National Institute of Health, Bethesda, Maryland, USA) was used for image analysis. Ten different non-overlapping randomly selected fields from each slide were examined at a magnification of 400 to quantitatively evaluate:

1. Mean mucosal thickness of the gastric mucosa (in H\&E stained sections).

2. Mean color intensity and area percentage of PAS positive histochemical reaction

3. Mean percentage (proliferation index) of Ki67immunohistochemical positive cells (in DABstained sections).

4. Mean color intensity and area percentage of positive iNOS immunohistochemical reaction (in DAB-stained sections)

\section{Statistical analysis}

The data were analyzed by using one-way analysis of variance (ANOVA) followed by Tukey's test for comparison between the groups using statistical package for social sciences statistical analysis software (IBM SPSS Statistics for Windows, IBM Corp, Version 22.0. Armonk, NY, USA). All the values were expressed as mean \pm standard deviation. Differences were considered significant if probability value $p<0.05$ and highly significant if $p<0.001^{[37]}$.

\section{RESULTS}

\section{H\&E histological staining}

Examination of sections of glandular gastric mucosa from both control and riboflavin-treated groups showed similar histological findings. The mucosa was composed of a surface epithelium and lamina propria containing gastric glands. The gastric glands appeared narrow, straight and perpendicular to the surface of the luminal epithelium occupying the whole thickness of the lamina propria. The lining epithelium was formed of simple columnar cells with basal oval nuclei and pale apical cytoplasm. The isthmus part of the gland next to the pits was lined by surface mucus-secreting cells and parietal cells. The neck region showed parietal cells and mucus neck cells, which had flat basal nuclei and pale foamy cytoplasm. The parietal cells appeared pyramidal to ovoid with central rounded nuclei and eosinophilic cytoplasm. The base showed predominance of chief cells. They appeared low columnar with basal oval nuclei, basal basophilic cytoplasm and pale apical granular part (Fig. 1).

Microscopic examination of the fundic gastric mucosa from tartrazine-treated group depicted variable degrees of mucosal lesions. Some sections revealed erosion of the surface mucosa with marked decrease in its thickness and exfoliated cells were seen in the lumen (Fig. 2). Wide distorted, irregular and discontinuous gastric glands were also observed (Fig. 3). The surface lining columnar cells appeared dark with pyknotic or irregular nuclei. The surface mucus cells were destroyed with distorted nuclei. Parietal cells showed marked vacuolization of the cytoplasm with irregular nuclei. Vacuolated chief cells with pyknotic nuclei were detected (Figs. 2, 3). In other sections, the fundic glands were disorganized and widely separated by dilated congested blood vessels. Some glands appeared atrophied with aggregated mononuclear cells in the lamina propria. Mononuclear cells could be seen infiltrating into the submucosa with wide spacing of connective tissue fibers (Figs. 4, 5).

Sections from tartrazine-recovery group showed an almost intact gastric mucosa, yet focally exfoliated surface mucosa and dilated congested blood vessels were observed. Some sections showed vacuolated parietal cells in addition to some vacuolated chief cells with pyknotic nuclei (Fig. 6).

Sections from tartrazine-recovery and riboflavin group showed a near normal gastric mucosa. Irregularity in few gastric glands with few pyknotic nuclei and vacuolated cytoplasm could be observed (Fig. 7).

Morphometric analysis of the mean mucosal thickness of the gastric mucosa revealed a highly significant decrease in tartrazine-treated group $(291.91 \pm 22.99)$ compared to the control group (487.66 \pm 55.29$)$, whereas tartrazine-recovery group (431.38 \pm 56.64$)$ showed a significant increase compared to the control. On the other hand, tartrazinerecovery and riboflavin group (479.94 \pm 43.98$)$ expressed a non-significant difference from the control (Table 1, Histogram 1A)

\section{PAS histochemical staining}

Microscopic examination of sections from control group showed the characteristic magenta red color of PASpositive film of mucin mainly on the surface epithelium and gastric pits (Fig. 8). While sections from tartrazinetreated group revealed a faint PAS-positive mucus film with a depleted neutral mucus secretion mainly on the surface and pits (Fig. 9). On the other hand, sections from tartrazine-recovery group showed moderate interrupted PAS-positive mucus film (Fig. 10). Nevertheless, section from tartrazine-recovery and riboflavin group depicted a near normal strong PAS-positive reaction (Fig. 11).

Morphometric analysis of the mean color intensity and area percentage of the PAS positive histochemical reaction revealed a highly significant decrease in tartrazine-treated group $(12.60 \pm 1.26,10.22 \pm 0.74$ respectively) compared to the control group $(32.29 \pm 2.58,27.45 \pm 1.83$ respectively), whereas tartrazine-recovery group $(27.93 \pm 4.65$, $22.94 \pm 4.88$ respectively) showed a significant decrease compared to the control. On the other hand, tartrazinerecovery and riboflavin group $(30.94 \pm 5.68,25.87 \pm 4.41$ respectively) expressed a non-significant difference from the control (Table 1, Histogram 1B). 


\section{Immunohistochemical staining for detection of Ki67}

Ki67-immunohistochemical stained sections from control group revealed many Ki67 positive cells with a moderately strong nuclear immunohistochemical reaction in the form of a brownish coloration mainly in the isthmus and neck regions (Fig. 12). While sections obtained from tartrazine-treated group showed numerous Ki67 positive cells with a strong nuclear reaction throughout the length of the gastric glands (Fig. 13). Nevertheless, sections from tartrazine-recovery group depicted numerous Ki67 positive cells with a moderately strong nuclear reaction throughout the length of the gastric glands (Fig. 14). Yet, sections from tartrazine-recovery and riboflavin group revealed many Ki67 positive cells with a moderately strong nuclear immunohistochemical reaction mainly in the isthmus and neck regions (Fig. 15).

Morphometric analysis of the mean percentage of Ki67 immunopositive cells revealed a highly significant increase in tartrazine-treated group $(56.45 \pm 6.90)$ compared to the control group (35.88 \pm 4.59$)$, whereas tartrazine-recovery group (40.48 \pm 4.44$)$ showed a significant increase compared to the control. On the other hand, tartrazine-recovery and riboflavin group (37.80 \pm 7.83$)$ expressed a non-significant difference from the control (Table 1, Histogram 1C).

Immunohistochemical staining for detection of iNOS

iNOS-immunohistochemical stained sections from control group revealed a faint iNOS immunohistochemical positive cytoplasmic reaction in the form of a brownish coloration mainly in the basal regions (Fig. 16). While sections obtained from tartrazine-treated group showed a strong iNOS immunohistochemical positive cytoplasmic reaction mainly in the basal regions (Fig 17). Nevertheless, sections from tartrazine-recovery group depicted a moderate iNOS immunohistochemical positive cytoplasmic reaction mainly in the basal regions (Fig. 18). Yet, sections from tartrazine-recovery and riboflavin group could show a faint iNOS immunohistochemical positive cytoplasmic reaction mainly in the basal regions (Fig. 19).

Morphometric analysis of the mean color intensity and area percentage of iNOS immunohistochemical positive reaction revealed a highly significant increase in tartrazine-treated group $(36.85 \pm 5.13,29.77 \pm 3.64$ respectively) compared to the control group (11.96 \pm 2.32 , $4.29 \pm 1.91$ respectively), whereas tartrazine-recovery group $(16.91 \pm 5.85,9.17 \pm 4.13$ respectively) showed a significant increase compared to the control. On the other hand, tartrazine-recovery and riboflavin group (13.01 \pm 5.33 , $5.95 \pm 1.25$ respectively) expressed a non-significant difference from the control (Table 1, Histogram 1D).

\section{Electron microscopic findings}

Examination of ultrathin sections of the glandular gastric mucosa of control rats showed parietal cells with rounded euchromatic nuclei. The cytoplasm showed intracellular canaliculi lined by finger-like microvilli, numerous mitochondria and multiple tubulovesicular structures
(Fig. 20). The chief cells showed oval euchromatic nuclei with prominent nucleoli. The cytoplasm depicted a welldeveloped Golgi apparatus, packed cisternae of rough endoplasmic reticulum and multiple variable sized electron lucent granules (Fig. 21).

Examination of ultrathin sections of the glandular gastric mucosa of tartrazine-treated group revealed parietal cells with abnormal features; nuclei with peripheral condensation of heterochromatin and dilated perinuclear cisternae and rough endoplasmic reticulum, wide dilation of the intracellular canaliculi with disrupted microvilli, irregularly shaped mitochondria and areas of cytoplasmic loss (Figs. 22,23). The chief cells depicted shrunken electron-dense nuclei with condensed heterochromatin, dilated cisternae of rough endoplasmic reticulum and few secretory granules (Fig. 23).

Ultrathin sections from the tartrazine-recovery group showed parietal cells with nuclei with peripheral condensation of heterochromatin and irregularly shaped mitochondria, the chief cells revealed shrunken electrondense nuclei with condensed heterochromatin and some dilated cisternae of rough endoplasmic reticulum and some secretory granules (Fig. 24).

Examination of ultrathin sections from the tartrazinerecovery and riboflavin group depicted apparently normal parietal cells with euchromatic nuclei, intracellular canaliculi and numerous mitochondria. The chief cells were near normal with almost oval euchromatic nuclei with prominent nucleoli, regular cisternae of rough endoplasmic reticulum and multiple variable sized electron lucent granules (Fig. 25).

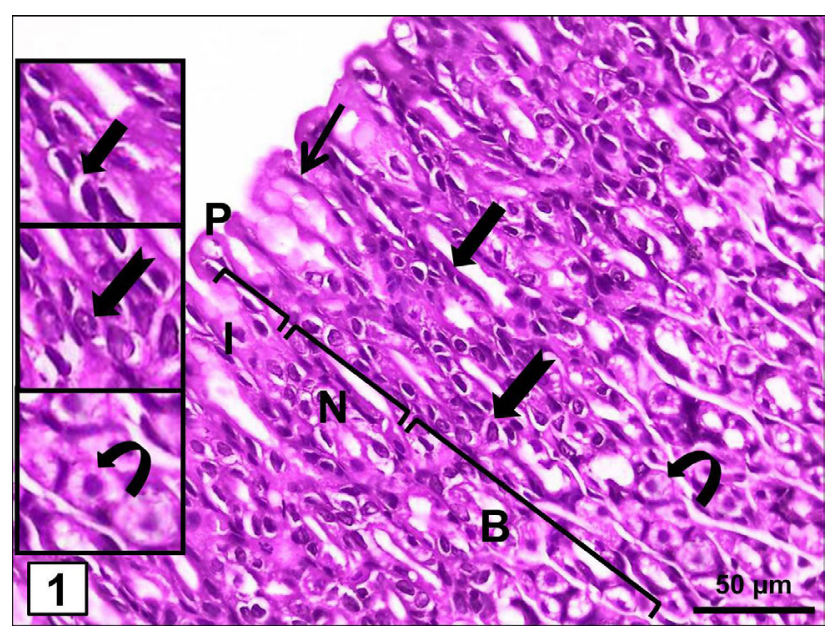

Fig. 1: A photomicrograph of the glandular gastric mucosa from control rat showing the gastric glands which appear narrow, straight, and perpendicular to the luminal epithelium opening with pits $(\mathrm{P})$ at the surface and divided into isthmus (I), neck (N) and base (B). The lining epithelium is formed of simple columnar cells (thin arrow) with basal oval nuclei and pale apical cytoplasm. The mucus neck cells (thick arrows) have flat basal nuclei and pale foamy cytoplasm. The parietal cells are pyramidal to ovoid (notched arrow) with central rounded nuclei and eosinophilic cytoplasm. The chief cells (curved arrow) appear low columnar with basal oval nuclei, basal basophilic cytoplasm, and pale apical granular part. (H\&E x 400, scale bar $=50 \mu \mathrm{m}$, inset x1000) 


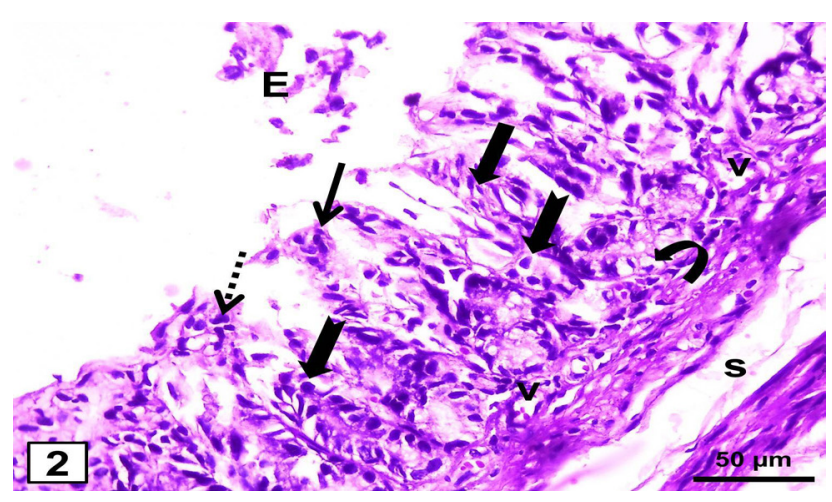

Fig. 2: A photomicrograph of the glandular gastric mucosa from tartrazinetreated group showing erosion of the surface mucosa with exfoliated cells (E) seen in the lumen. The surface lining columnar cells appear dark with pyknotic (thin arrow) or irregular nuclei (thin dotted arrow). The surface mucous cells are destroyed with distorted nuclei (thick arrow). Parietal cells show marked vacuolization of the cytoplasm (notched arrows). Vacuolated chief cells with pyknotic nuclei can be detected (curved arrow). Notice some congested blood vessels (v) and wide separation underlying the mucosa (s). (H\&E x 400, scale bar=50 $\mu \mathrm{m})$

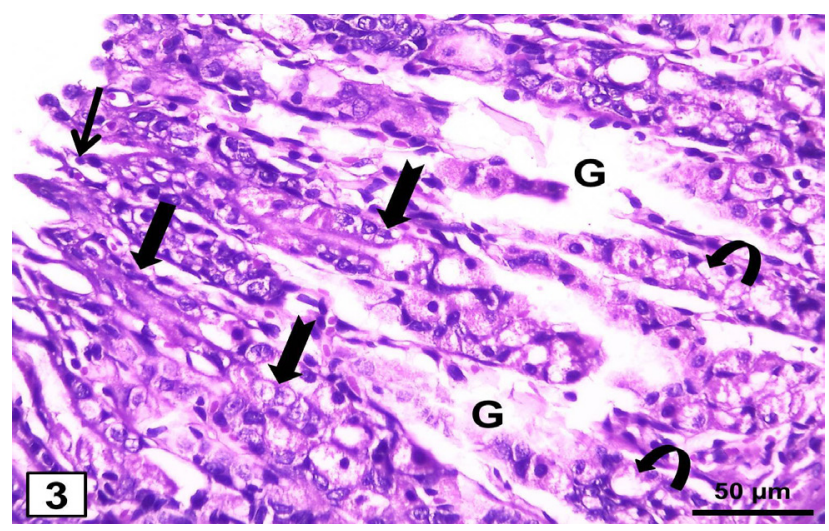

Fig. 3: A photomicrograph of the glandular gastric mucosa from tartrazinetreated group showing wide distorted, irregular and discontinuous gastric glands (G). The surface lining columnar cells appear dark with pyknotic nuclei (thin arrow). The surface mucous cells are destroyed with distorted nuclei (thick arrow). Parietal cells show marked vacuolization of the cytoplasm with irregular nuclei (notched arrow). Vacuolated chief cells with pyknotic nuclei can be detected (curved arrow). (H\&E x 400, scale bar $=50 \mu \mathrm{m})$

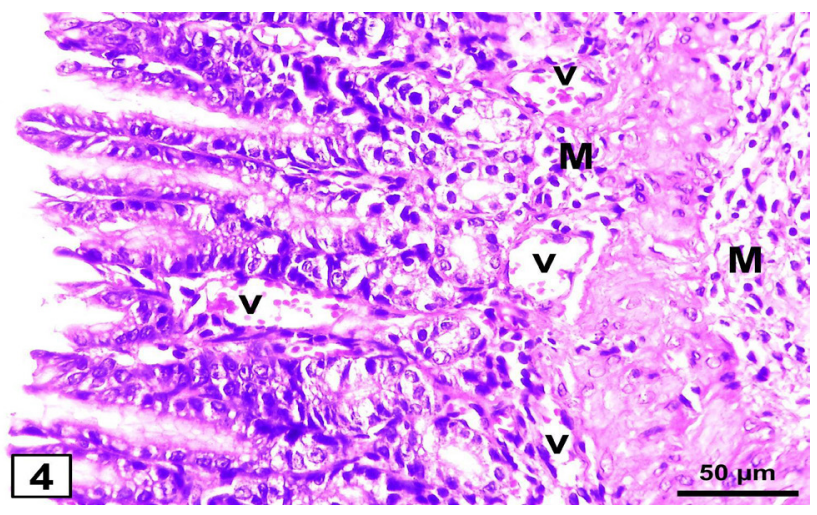

Fig. 4: A photomicrograph of the glandular gastric mucosa from tartrazinetreated group showing disorganized fundic glands widely separated by dilated congested blood vessels (v). Notice some mononuclear cells (M) in the lamina propria and infiltrating down to the muscularis mucosa and submucosa. $(\mathrm{H} \& \mathrm{E}$ x 400 , scale bar $=50 \mu \mathrm{m})$

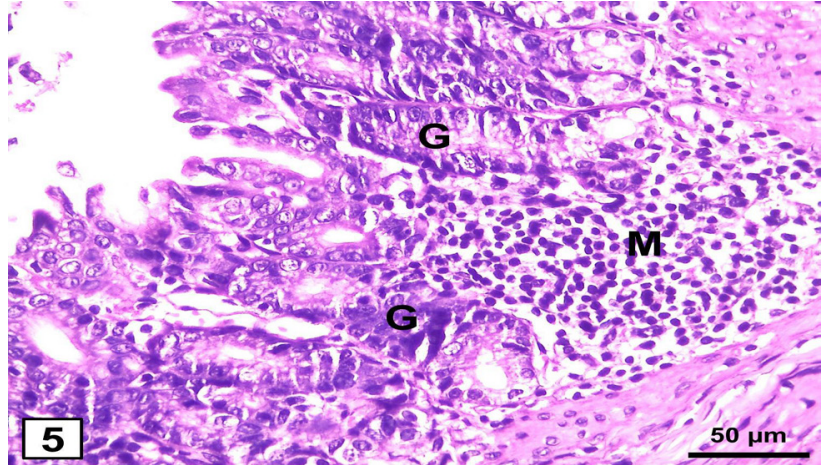

Fig. 5: A photomicrograph of the glandular gastric mucosa from tartrazine-treated group showing disorganized atrophic fundic glands $(\mathrm{G})$ with mononuclear cells aggregation $(\mathrm{M})$ in the lamina propria infiltrating down to the muscularis mucosa. $(\mathrm{H} \& \mathrm{E} \times 400$, scale bar=50 $\mu \mathrm{m})$

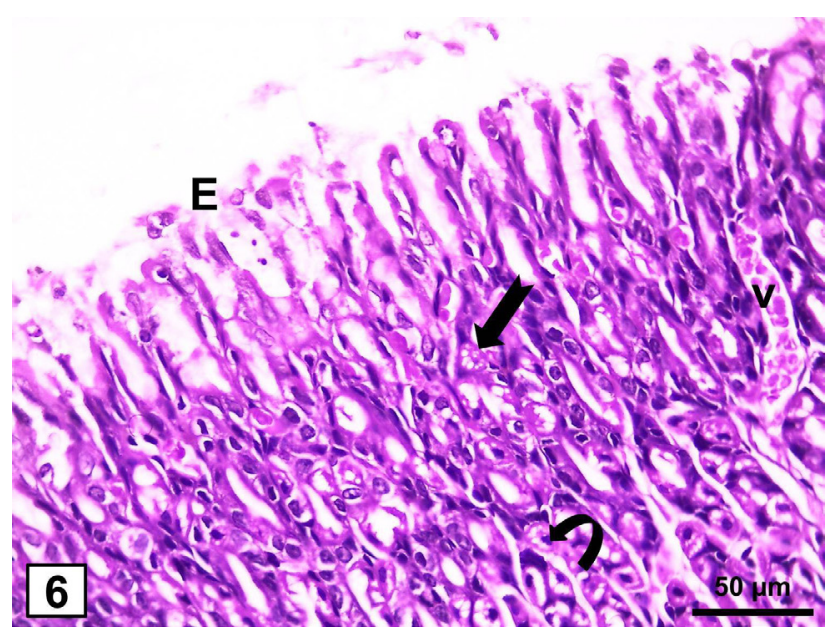

Fig. 6: A photomicrograph of the glandular gastric mucosa from tartrazine-recovery group showing almost intact gastric mucosa. Notice focally exfoliated surface mucosa (E), dilated congested blood vessels (v), Some parietal cells show vacuolization of the cytoplasm (notched arrow). Vacuolated chief cells with pyknotic nuclei can be detected (curved arrow). (H\&E x 400, scale bar $=50 \mu \mathrm{m}$ )

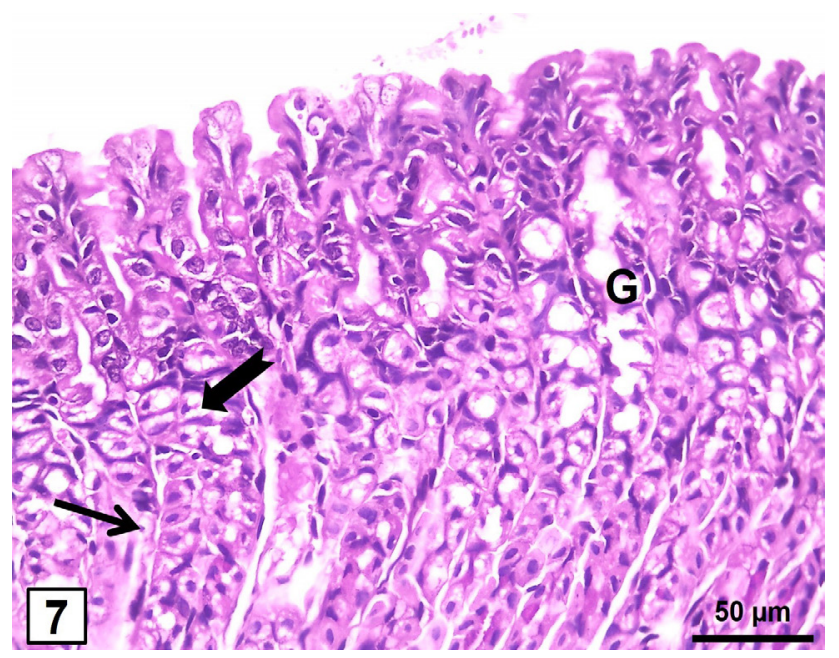

Fig. 7: A photomicrograph of the glandular gastric mucosa from tartrazine-recovery and riboflavin group showing a near normal gastric mucosa. Notice irregularity in few gastric glands $(\mathrm{G})$ with few pyknotic nuclei (thin arrow) and vacuolated cytoplasm (notched arrow). (H\&E x 400 , scale bar $=50 \mu \mathrm{m})$ 


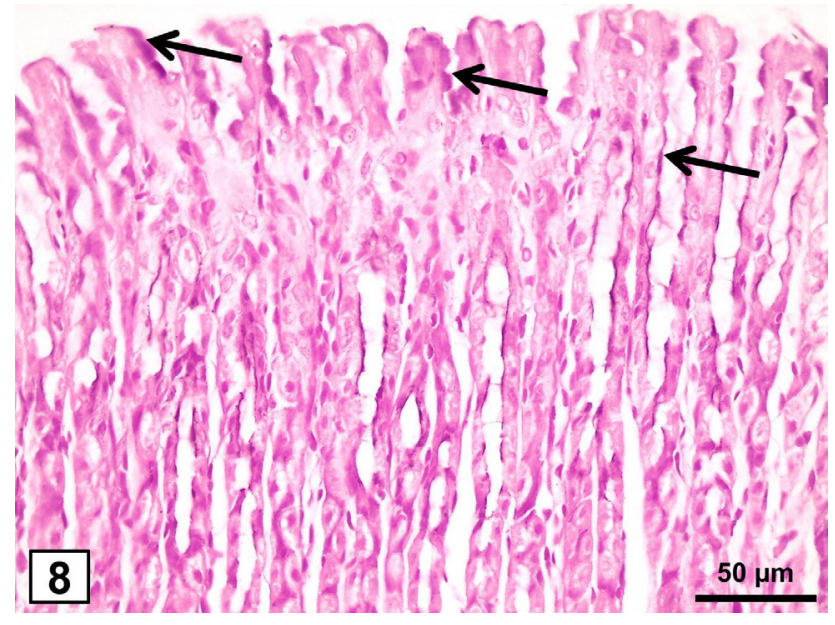

Fig. 8: A photomicrograph of the glandular gastric mucosa from control rat showing the characteristic magenta red color of PAS-positive film of mucin mainly on the surface epithelium and gastric pits (arrows) (PAS x 400 , scale bar $=50 \mu \mathrm{m})$

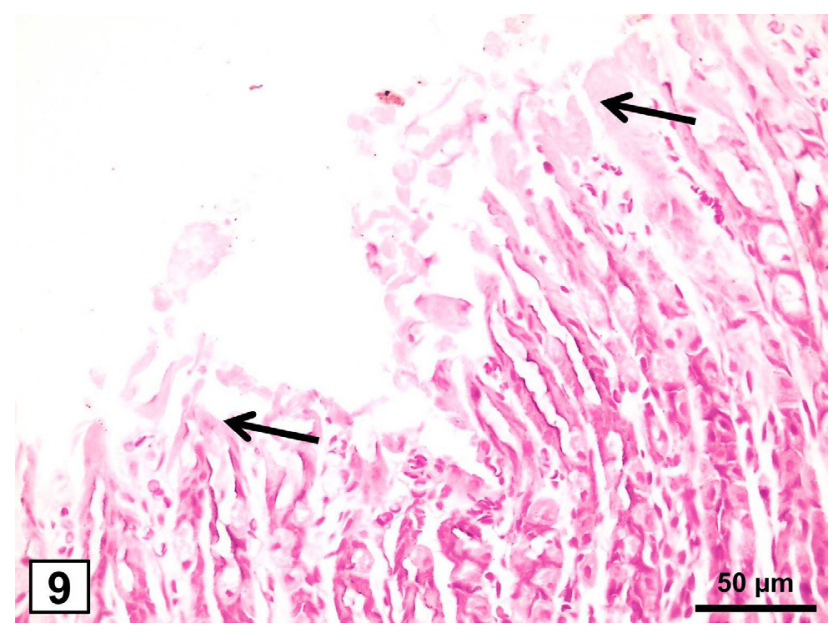

Fig. 9: A photomicrograph of the glandular gastric mucosa from tartrazine-treated group showing faint PAS-positive mucus film with depleted neutral mucus secretion mainly on the surface and pits (arrows). (PAS x 400, scale bar $=50 \mu \mathrm{m})$

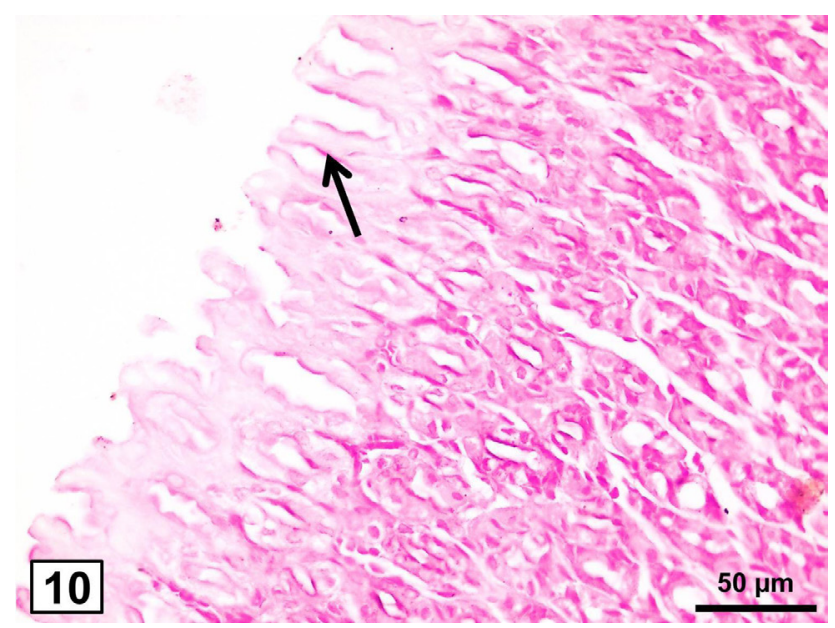

Fig. 10: A photomicrograph of the glandular gastric mucosa from tartrazine-recovery group showing moderate interrupted PAS-positive mucus film (arrow). (PAS x 400, scale bar=50 $\mu \mathrm{m}$ )

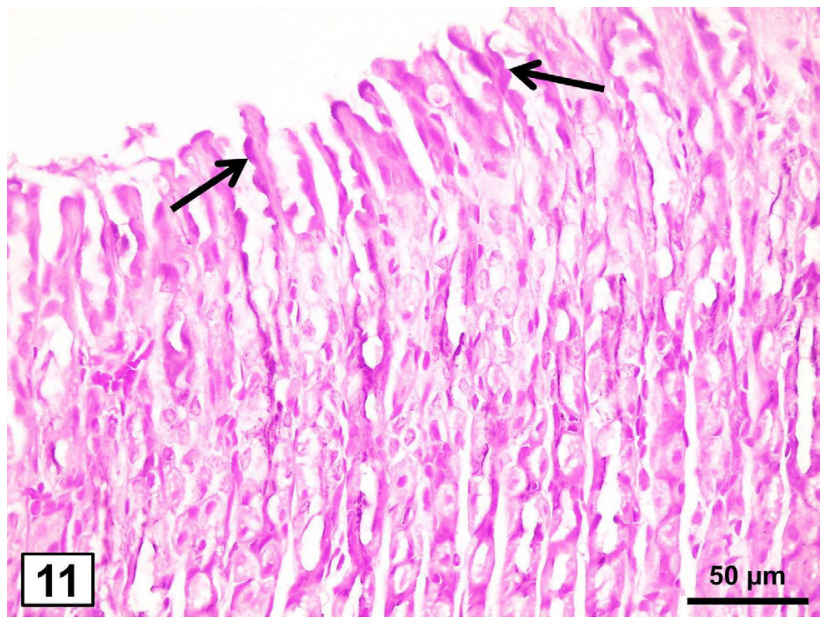

Fig. 11: A photomicrograph of the glandular gastric mucosa from tartrazine-recovery and riboflavin showing a near normal strong PASpositive film of mucin mainly on the surface epithelium and gastric pits (arrows). (PAS x 400, scale bar=50 $\mu \mathrm{m}$ )

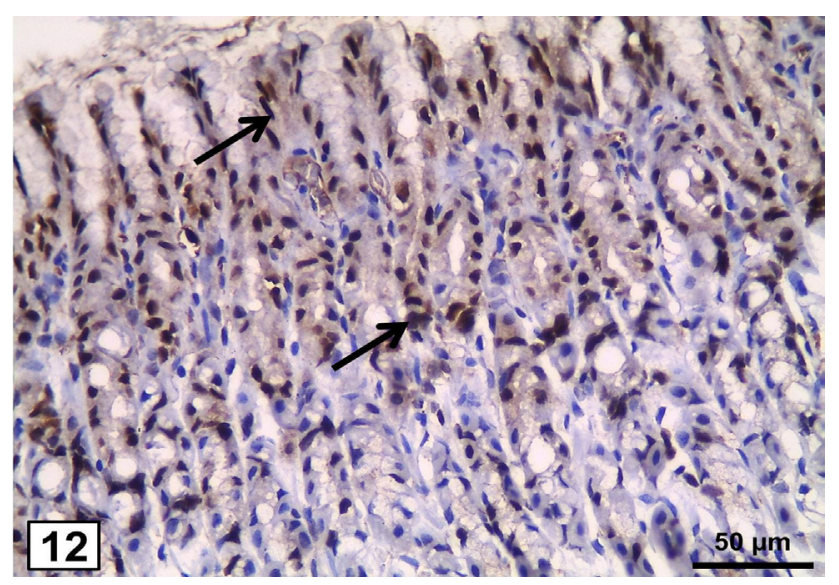

Fig. 12: A photomicrograph of the glandular gastric mucosa from control rat showing many Ki67 positive cells with a moderately strong nuclear immunohistochemical reaction in the form of a brownish coloration mainly in the isthmus and neck regions (arrows). (Ki67 x 400, scale bar $=50 \mu \mathrm{m})$

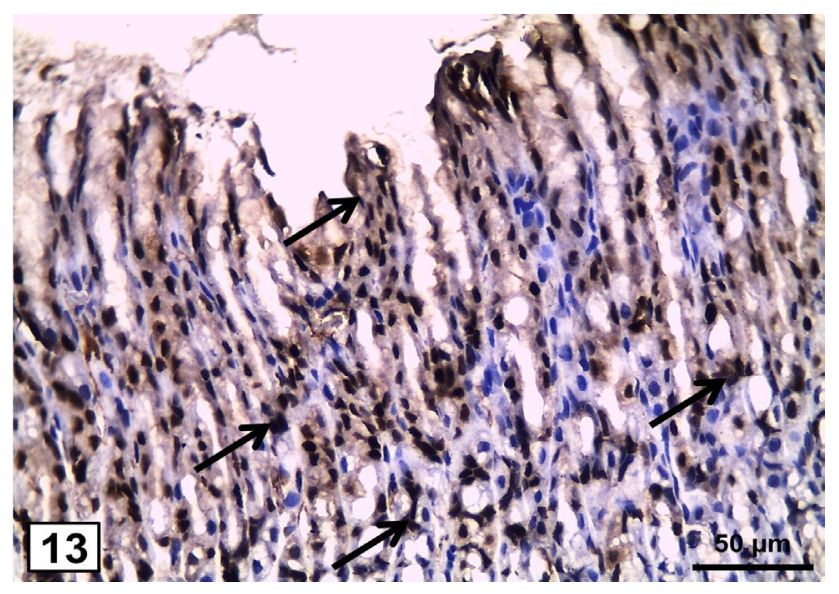

Fig. 13: A photomicrograph of the glandular gastric mucosa from tartrazine-treated group showing numerous Ki67 positive cells with a strong nuclear reaction throughout the length of the gastric glands (arrows). (Ki67 x 400, scale bar $=50 \mu \mathrm{m}$ ) 


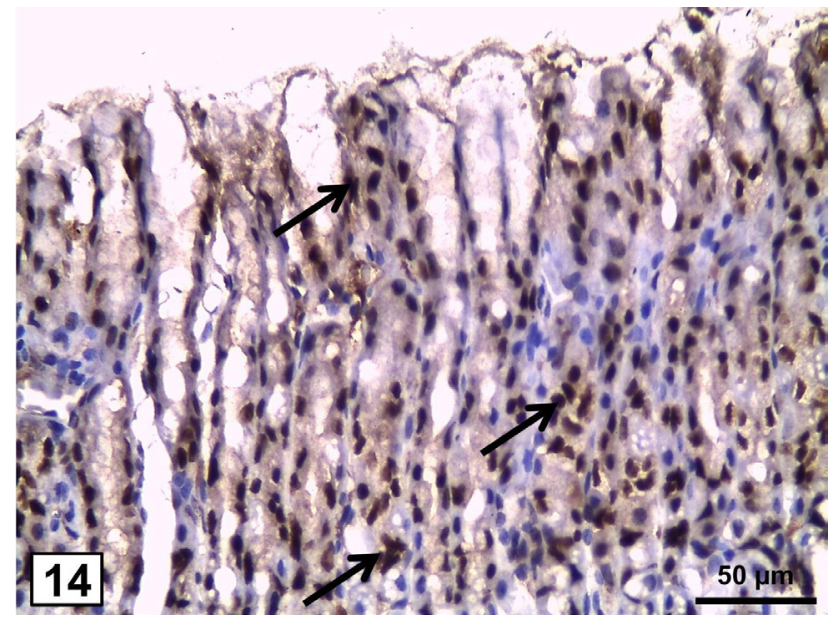

Fig. 14: A photomicrograph of the glandular gastric mucosa from tartrazine-recovery group showing numerous Ki67 positive cells with a moderately strong nuclear reaction throughout the length of the gastric glands (arrows). (Ki67 x 400, scale bar=50 $\mu \mathrm{m}$ )

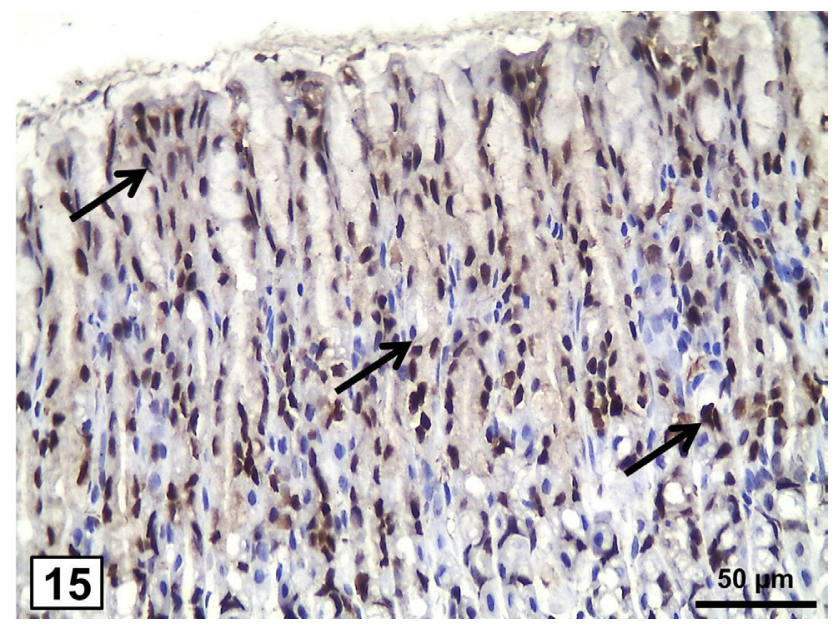

Fig. 15: A photomicrograph of the glandular gastric mucosa from tartrazine-recovery and riboflavin group showing many Ki67 positive cells with a moderately strong nuclear reaction mainly in the isthmus and neck regions (arrows). (Ki67 x 400, scale bar=50 $\mu \mathrm{m})$

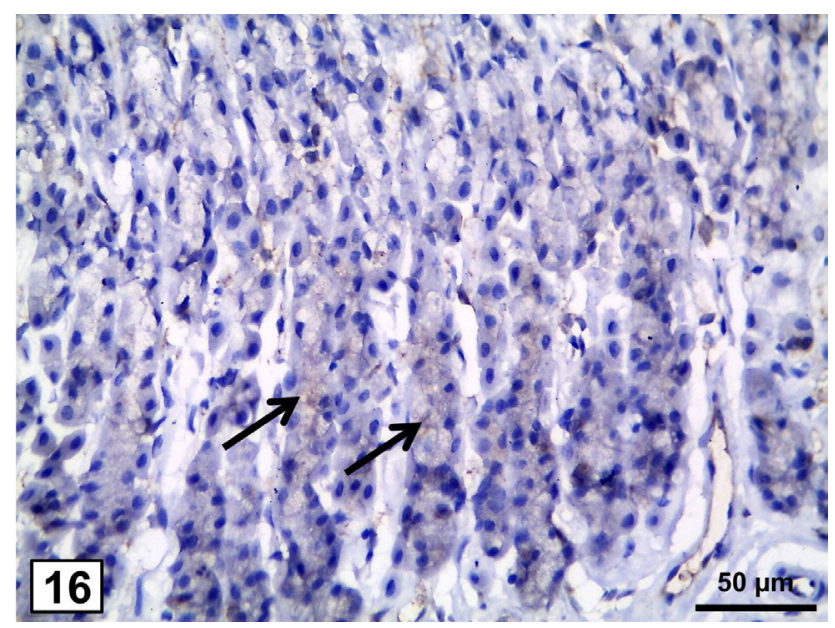

Fig. 16: A photomicrograph of the glandular gastric mucosa from control rat showing a faint iNOS immunohistochemical positive cytoplasmic reaction in the form of a brownish coloration mainly in the basal regions (arrows). (iNOS x 400, scale bar=50 $\mu \mathrm{m}$ )

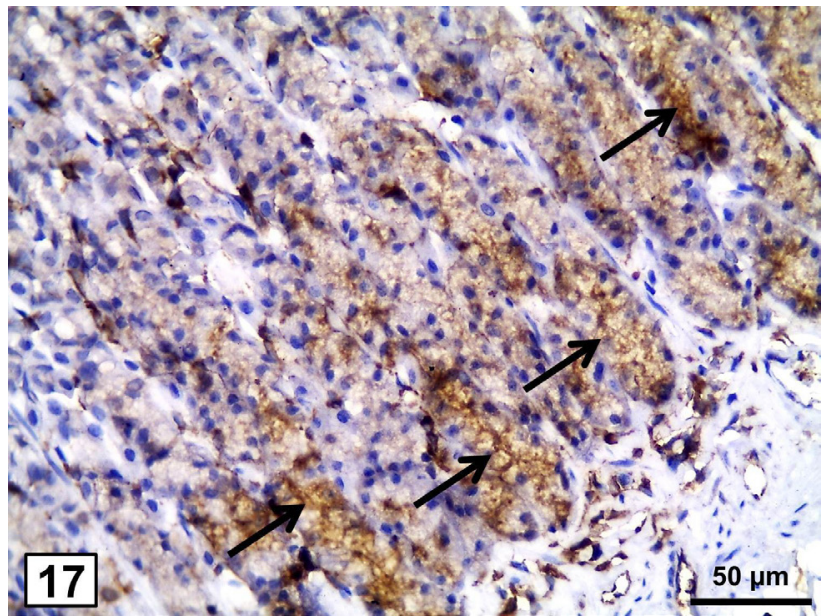

Fig. 17: A photomicrograph of the glandular gastric mucosa from tartrazine-treated group showing a strong iNOS immunohistochemical positive cytoplasmic reaction mainly in the basal regions (arrows). (iNOS x 400 , scale bar $=50 \mu \mathrm{m})$

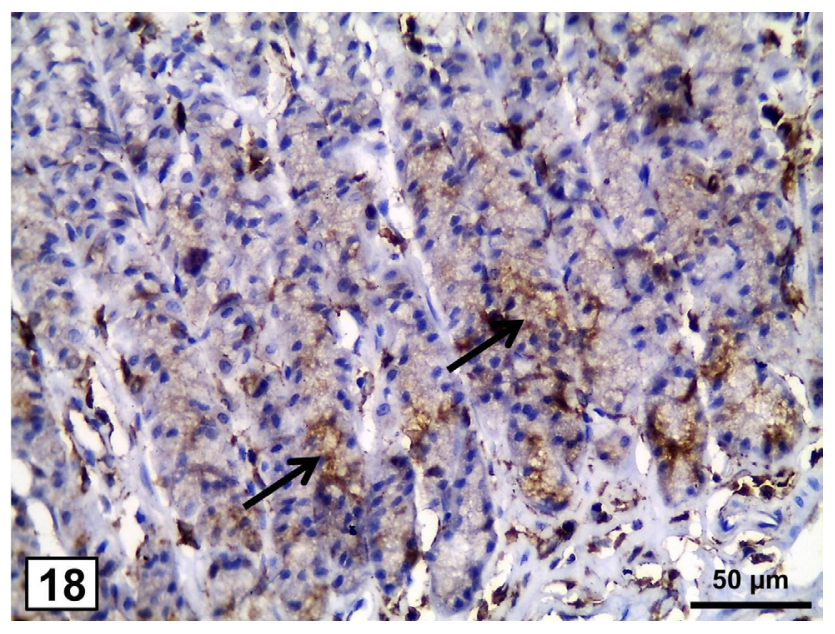

Fig. 18: A photomicrograph of the glandular gastric mucosa from tartrazinerecovery group showing a moderate iNOS immunohistochemical positive cytoplasmic reaction mainly in the basal regions (arrows). (iNOS x 400, scale bar $=50 \mu \mathrm{m})$

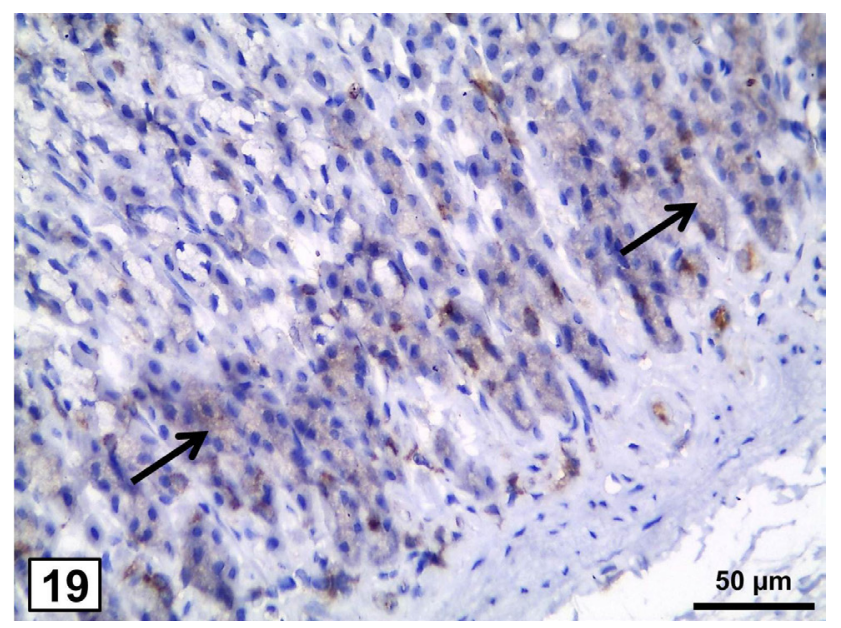

Fig. 19: A photomicrograph of the glandular gastric mucosa from tartrazine-recovery and riboflavin group showing a faint iNOS immunohistochemical positive cytoplasmic reaction mainly in the basal regions (arrows). (iNOS x 400, scale bar $=50 \mu \mathrm{m}$ ) 


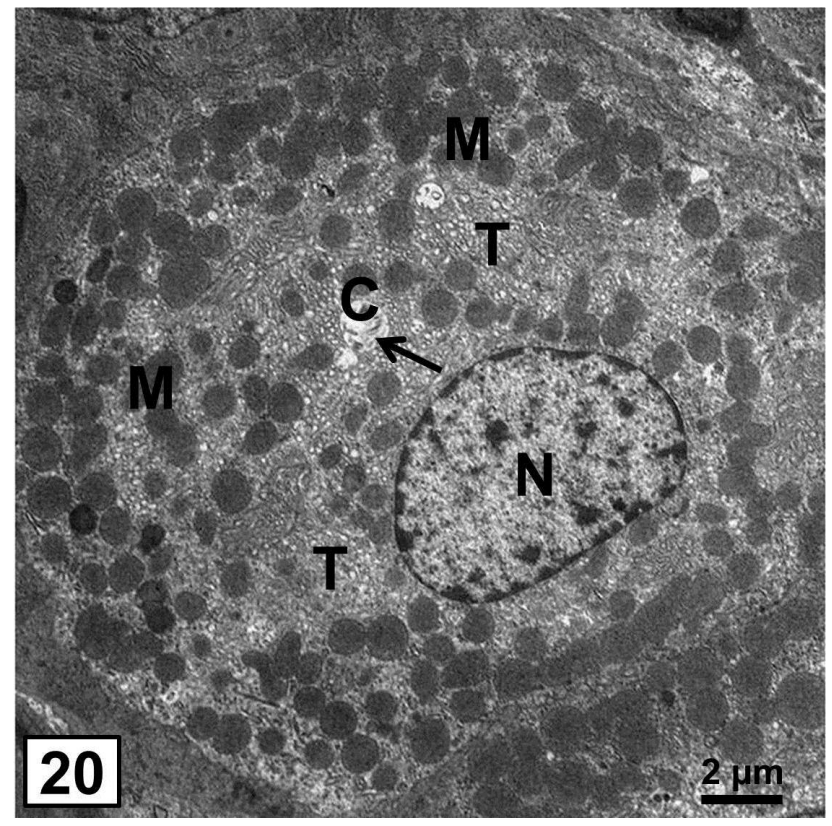

Fig. 20: An electron photomicrograph from control group showing a parietal cell with rounded euchromatic nucleus $(\mathrm{N})$. The cytoplasm shows apical intracellular canaliculi (C) with microvilli (thin arrow), numerous mitochondria (M) and multiple tubulovesicular structures $(\mathrm{T})$.

(TEMx8780, scale bar=2 $\mu \mathrm{m})$

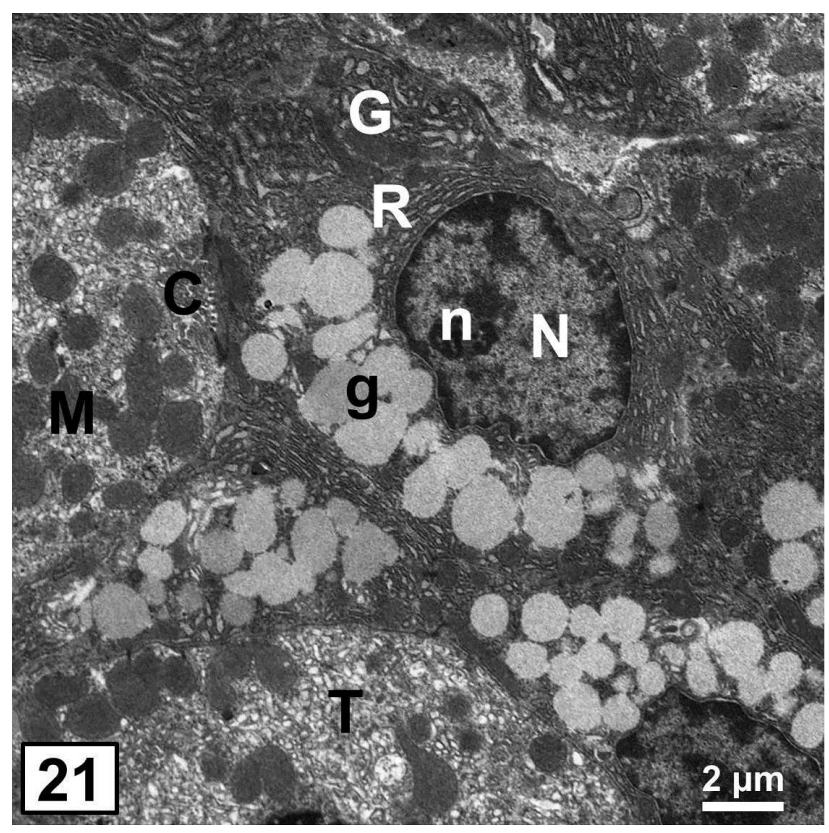

Fig. 21: An electron photomicrograph from control group showing a chief cell with oval euchromatic nucleus $(\mathrm{N})$ and a prominent nucleolus (n). The cytoplasm depicts a well-developed Golgi apparatus $(\mathrm{G})$, packed cisternae of rough endoplasmic reticulum (R) and multiple variable sized electron lucent granules (g). Notice parts of adjacent parietal cells showing canaliculi (C), numerous mitochondria (M) and tubulovesicular structures (T). (TEMx8780, scale bar $=2 \mu \mathrm{m})$

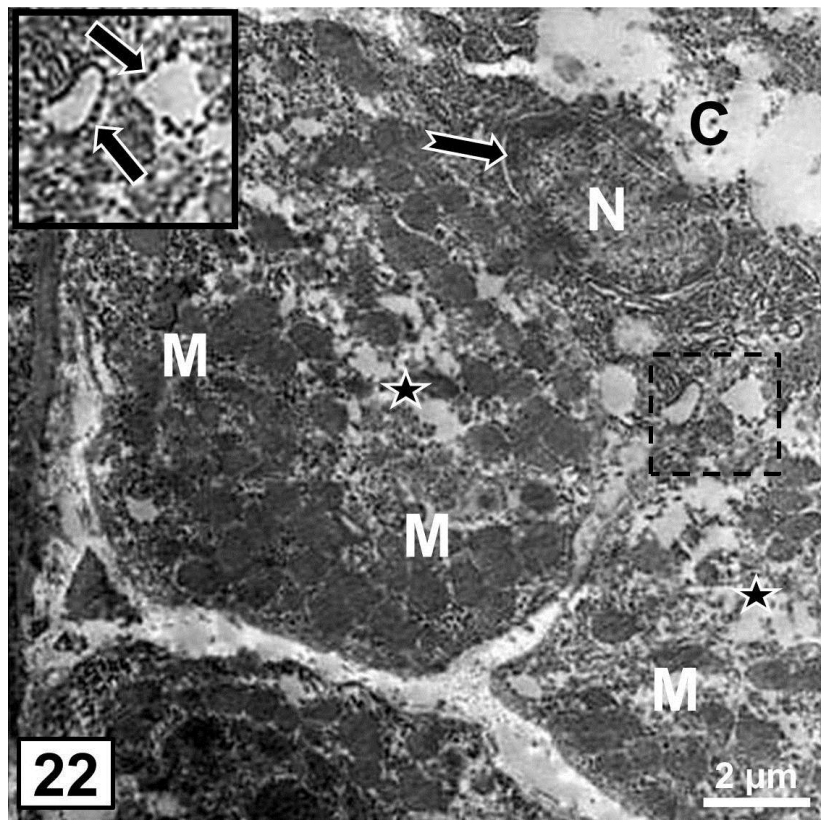

Fig. 22: An electron photomicrograph from tartrazine-treated group showing a parietal cell with a nucleus with peripheral condensation of heterochromatin $(\mathrm{N})$, dilated perinuclear cisternae (notched arrow) and rough endoplasmic reticulum (thick arrows in inset), wide dilation of the intracellular canaliculi $(\mathrm{C})$ with disrupted microvilli, irregularly shaped mitochondria (M) and areas of cytoplasmic loss (stars). [dashed square represents the inset] (TEMx11700, scale bar=2 $\mu \mathrm{m}$, inset $\mathrm{x} 17560)$

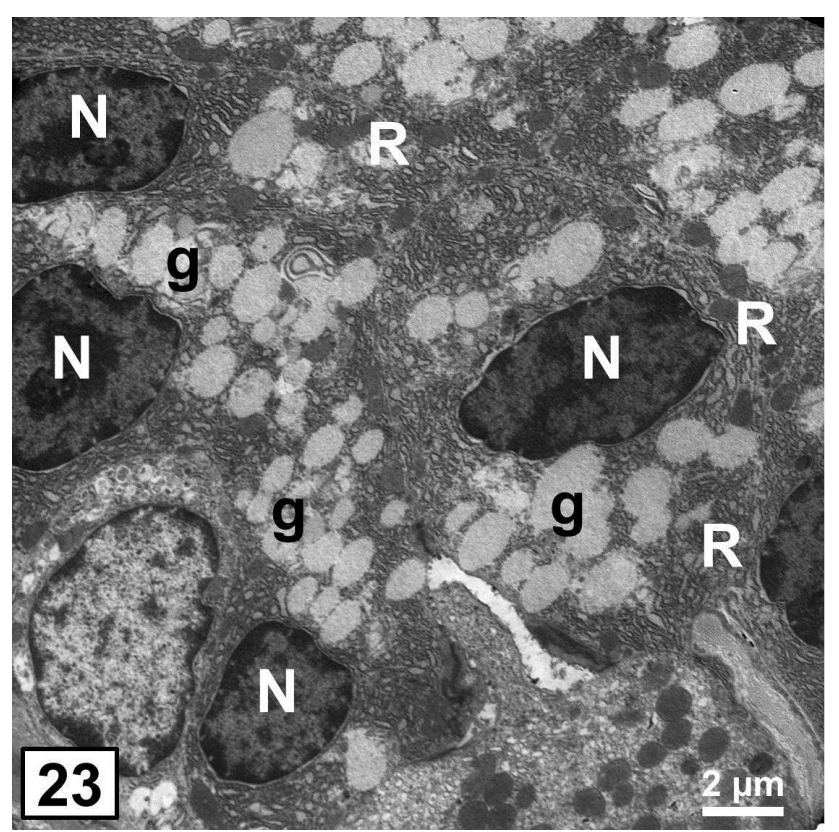

Fig. 23: An electron photomicrograph from tartrazine-treated group showing multiple chief cells depicting shrunken electron-dense nuclei with condensed heterochromatin $(\mathrm{N})$, dilated cisternae of rough endoplasmic reticulum (R) and few secretory granules (g). (TEMx8780, scale bar $=2 \mu \mathrm{m}$ ) 


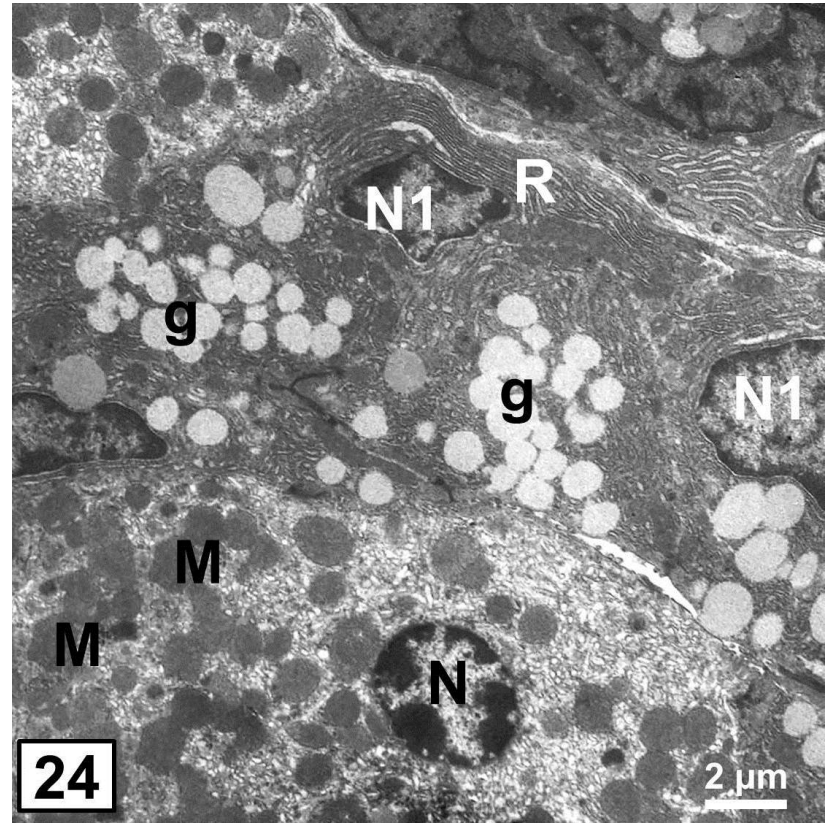

Fig. 24: An electron photomicrograph from tartrazine-recovery group showing parietal cells with nuclei with peripheral condensation of heterochromatin $(\mathrm{N})$ and irregularly shaped mitochondria $(\mathrm{M})$, chief cells with shrunken electron-dense nuclei with condensed heterochromatin (N1) and some dilated cisternae of rough endoplasmic reticulum (R) and some secretory granules (g). (TEMx8780, scale bar=2 $\mu \mathrm{m})$

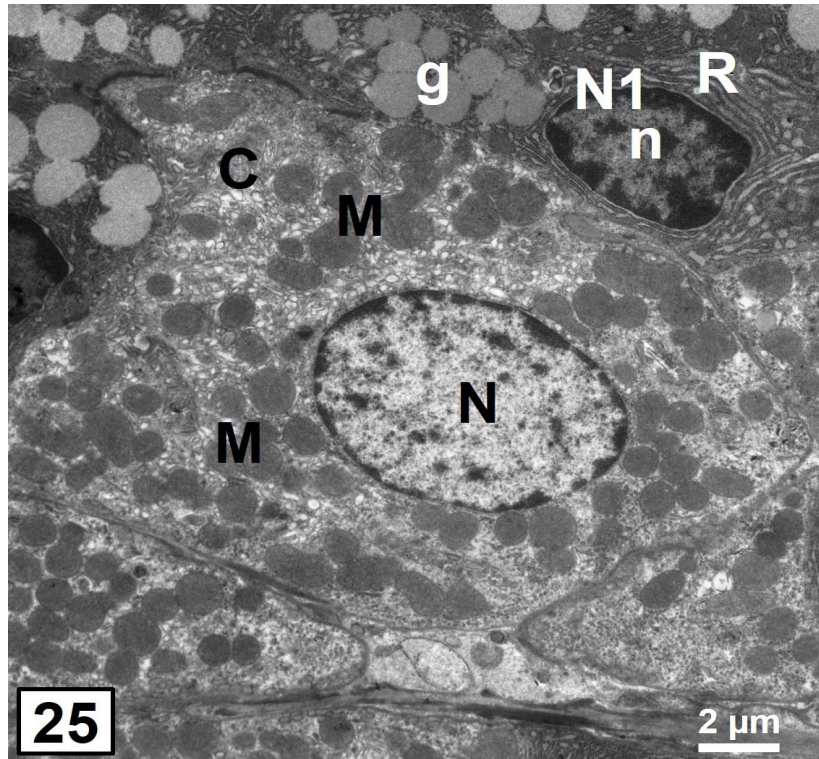

Fig. 25: An electron photomicrograph from tartrazine-recovery and riboflavin group showing apparently normal parietal cell with an euchromatic nucleus (N), intracellular canaliculi (C) and numerous mitochondria (M). A chief cell is nearly normal with an almost oval euchromatic nucleus (N1) with prominent nucleolus (n), regular cisternae of rough endoplasmic reticulum (R) and multiple variable sized electron lucent granules $(\mathrm{g})$. (TEMx8780, scale bar $=2 \mu \mathrm{m})$

Table 1: Morphometrical and statistical analysis of different study groups

\begin{tabular}{|c|c|c|c|c|c|c|}
\hline \multicolumn{2}{|l|}{ Parameters } & Group I & Group II & Group III & Group IV & Group V \\
\hline \multicolumn{2}{|l|}{ Mean mucosal thickness $(\mu \mathrm{m})$} & $487.66 \pm 55.29$ & $491.71 \pm 42.11$ & $291.91 \pm 22.99^{* *}$ & $431.38 \pm 56.64^{*}$ & $479.94 \pm 43.98$ \\
\hline \multirow{2}{*}{ PAS histochemical staining } & Mean color intensity & $32.29 \pm 2.58$ & $32.87 \pm 3.18$ & $12.60 \pm 1.26^{* *}$ & $27.93 \pm 4.65^{*}$ & $30.94 \pm 5.68$ \\
\hline & Mean area percentage & $27.45 \pm 1.83$ & $27.69 \pm 1.77$ & $10.22 \pm 0.74^{* *}$ & $22.94 \pm 4.88^{*}$ & $25.87 \pm 4.41$ \\
\hline \multicolumn{2}{|c|}{ Mean percentage $\%$ of Ki67-immunopositive cells } & $35.88 \pm 4.59$ & $35.23 \pm 3.76$ & $56.45 \pm 6.90^{* *}$ & $40.48 \pm 4.44^{*}$ & $37.80 \pm 7.83$ \\
\hline \multirow{2}{*}{ iNOS immunohistochemical reaction } & Mean color intensity & $11.96 \pm 2.32$ & $11.18 \pm 1.78$ & $36.85 \pm 5.13^{* *}$ & $16.91 \pm 5.85^{*}$ & $13.01 \pm 5.33$ \\
\hline & Mean area percentage & $4.29 \pm 1.91$ & $4.03 \pm 0.72$ & $29.77 \pm 3.64^{* *}$ & $9.17 \pm 4.13^{*}$ & $5.95 \pm 1.25$ \\
\hline
\end{tabular}

Data is expressed as mean \pm standard deviation. * indicates significant vs control, $* *$ indicates highly significant vs control.
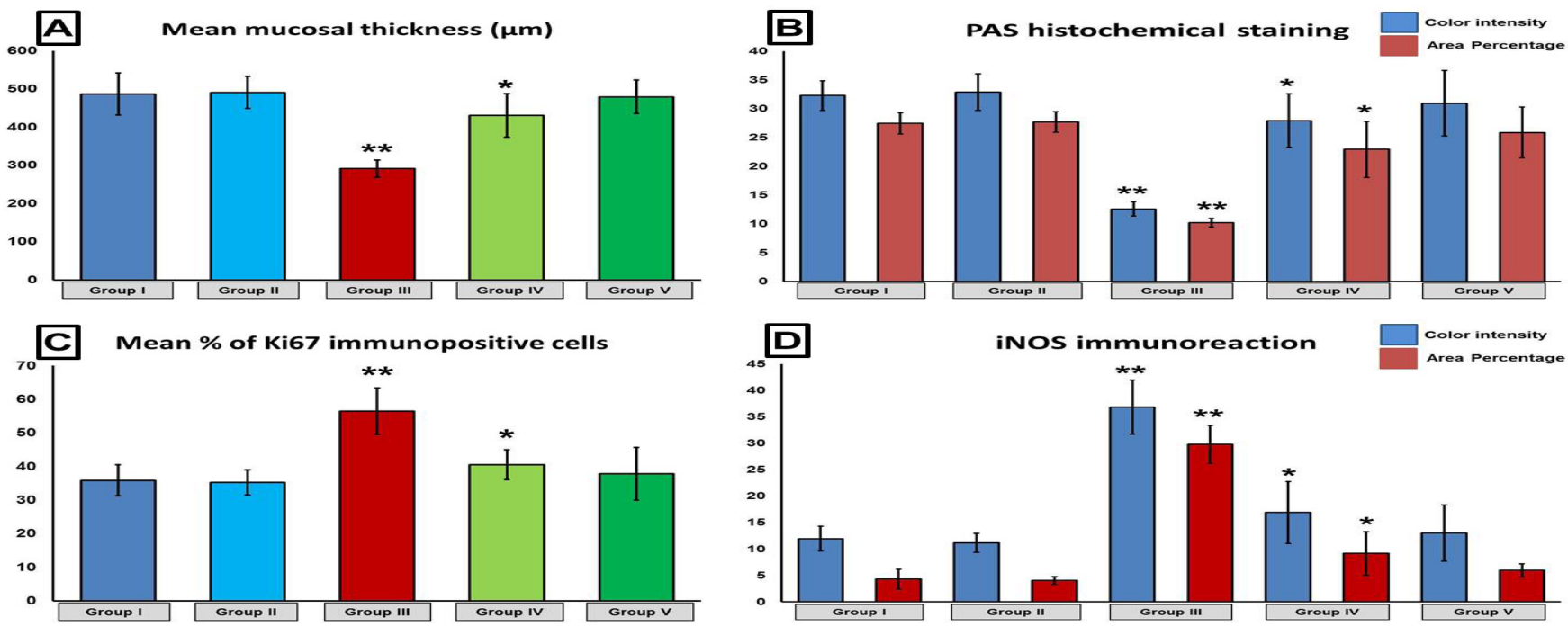

Histogram 1: Morphometric and statistical analysis: A] Mean mucosal thickness, B] Mean color intensity and area percentage of PAS histochemical reaction, C] Mean percentage of Ki67 immunohistochemical positive cells and D] Mean color intensity and area percentage of iNOS immunohistochemical reaction. * indicates significant vs control, ** indicates highly significant vs control. 


\section{DISCUSSION}

Progressive unregulated use of synthetic azo dyes such as tartrazine raises the attention to their benefit versus risk in food industry especially for the vulnerable groups. Some studies have reported the detrimental effects of tartrazine on different tissues and organs of experimental animals $^{[38,39]}$, whereas other studies have suggested that tartrazine was not hazardous ${ }^{[40]}$. Since the data regarding the toxicity of tartrazine are contradictory, the present work aimed to investigate the effect of tartrazine on the gastric mucosa of adult male albino rat and to evaluate the possible role of a recovery period after its withdrawal with or without riboflavin using different histological and immunohistochemical methods.

Both light and electron microscopic histological findings of the present study could demonstrate that oral administration of tartrazine for 60 days caused deleterious effects on the structure of gastric mucosa leading to various degrees of damage in the form of distorted and degenerated gastric glands together with some degenerative changes of the cells lining these glands. Moreover, atrophy of gastric mucosa was evident and manifested as a highly significant decrease in the thickness of the gastric mucosa after tartrazine administration compared with the control group. These results were similar to the data reported by some authors ${ }^{[41,42]}$. On contrary, few studies denied any harmful effects of tartrazine on the gastric mucosa ${ }^{[43]}$.

In addition, the current findings were in agreement with other studies ${ }^{[44]}$ that reported an evidence of degenerative and atrophic changes in the gastric mucosa in rats that were kept on monosodium glutamate which is another common food additive. Moreover, other studies reported that chronic administration of tartrazine resulted in variable degenerative changes in other organs such as liver and kidney ${ }^{[45,46]}$.

In the present study, the degenerated cellular lining of the gastric glands together with the exfoliated surface epithelial cells suggested that tartrazine might have a direct damaging effect on the cellular membranes with a subsequent permeability deficit. Another study ${ }^{[47]}$ described a similar mechanism in ethanol-induced gastric injury, where the rapid penetration of ethanol into the gastric mucosa led to a cell membrane damage with a subsequent increase in the intracellular membrane permeability to sodium and water with an increased calcium intracellular accumulation leading to cell death and surface epithelium exfoliation. In addition, the current results were going hand to hand with the data reported by some authors ${ }^{[48]}$ who studied the genotoxicity of tartrazine on glandular stomach and declared that tartrazine induced DNA damage in the gastric glands.

Tartrazine is metabolized into aromatic amines (sulfanilic acid) by the gastrointestinal microflora ${ }^{[49]}$ that can generate reactive oxygen species (ROS) as a part of their metabolism by the interaction of these amino groups with nitrite- or nitrate-containing food, thus promoting lipid peroxidation and inhibiting endogenous antioxidant defense enzymes resulting in acceleration of the oxidative stress ${ }^{[50]}$. Accordingly, some studies have attributed the gastric mucosal damage to the oxidative stress effect of tartrazine $^{[51]}$.

Nevertheless, the immunohistochemical results of the current work revealed that tartrazine stimulated iNOS expression as indicated by a statistically high significant increase in the mean color intensity and area percentage of iNOS immunohistochemical positive reaction in tartrazine-treated group compared to control. The iNOS is responsible for catalyzing the formation of nitric oxide (NO) from L-arginine ${ }^{[52]}$. It was stated that $\mathrm{NO}$ is important for normal mucosal function ${ }^{[53]}$ in addition to its cytoprotective effect on the gastrointestinal mucosa ${ }^{[54]}$. Moreover, NO is considered an important source of free radicals that might contribute to an energy metabolism alteration. It was suggested that the oxidative stress to epithelial cells increases their NO synthesis resulting in an increased nitrite production and subsequent decreased cell viability through developing nitrosative stress ${ }^{[55]}$.

In addition, the present study could reveal different signs of inflammation in the form of dilated congested blood vessels and interstitial edema indicated by a wide spacing of connective tissue fibers in addition to mononuclear cellular infiltration in the lamina propria of gastric mucosa of tartrazine-treated animals, these findings suggest inflammation to be one of the underlying mechanisms of tartrazine-induced gastric injury. Similarly, other studies recorded that tartrazine has induced inflammatory signs in other organs such as liver and kidney ${ }^{[56]}$. Furthermore, another study demonstrated an increased number of the inflammatory cells; lymphocytes and eosinophils in the gastric mucosa of tartrazine-treated animals ${ }^{[57]}$.

In this work, the tartrazine-treated group illustrated a faint PAS-positive mucus film with a depleted neutral mucus secretion mainly on the surface and pits of gastric glands, this was confirmed by the statistical analysis that revealed a highly significant decrease in the mean color intensity and area percentage of the PAS positive histochemical reaction in tartrazine-treated group compared to control, this could be attributed to the damaging effect of tartrazine on the gastric mucus cells which appeared destroyed with distorted nuclei in the histological findings of this work. It was suggested that the acidic mucin has an essential role in protecting the gastric pit cells against $\mathrm{HCl}$ during its passage. In addition, the alternating layers of neutral and acidic mucins in the gastric surface are reported to act as a barrier against both $\mathrm{HCl}$ and digestive enzymes ${ }^{[58]}$. Moreover, it was emphasized that the gastric mucus possesses antioxidant properties owing to its rich glycoprotein content ${ }^{[59]}$. Moreover, many studies linked the mucus barrier dysfunction to the oxidative stress and the development of inflammation ${ }^{[60]}$.

The current study could demonstrate that tartrazine increased the proliferation of epithelial cells of gastric mucosa as manifested by a highly significant increase in the 
mean percentage of Ki67-immunopositive cells compared to the control. Ki67 is an efficient marker of proliferation ${ }^{[61]}$, whose increased expression indicates an enhanced proliferative activity that allows for the regeneration of damaged epithelial and mucus-producing cells to renew the mucus protective layer, thus permitting the healing of the degenerated areas of the gastric mucosa ${ }^{[62]}$.

The current study examined the possible reversibility of tartrazine damaging effects on the gastric mucosa, it could be demonstrated that after stopping tartrazine administration for 60 days, there was a partial improvement in the gastric mucosa, but it still showed some focal exfoliation in the surface mucosa and some dilated congested blood vessels in addition to some vacuolated parietal and chief cells. Persistence of these alterations after cessation of tartrazine treatment may suggest either the need of more time for recovery or the urge of using of a proper adjuvant therapy.

In this study, riboflavin was chosen as an adjuvant therapy during the tartrazine recovery period where it led to an evident marked improvement in the different histological and immunohistochemical findings. This came in accordance with the data reported by other researchers who demonstrated that riboflavin promoted prostaglandin synthesis, mucus and bicarbonate secretion, mucosal blood flow and enhanced the resistance of epithelial cells to cytotoxins-induced injury while suppressing the recruitment of leukocytes into the gastric mucosa ${ }^{[63]}$. Nevertheless, riboflavin is a proteasome inhibitor capable of resolving inflammation through reducing the proinflammatory cytokines $^{[64,65]}$. This protective effect of riboflavin could be related to its intrinsic antioxidant potential that reduced the gastric mucosal expression of iNOS as indicated in the immunohistochemical results of this work, leading to the attenuation of the oxidative stress and the acute inflammatory response. Moreover, riboflavin is a cofactor for different enzymes involved in the oxidation-reduction reactions, and it plays a role in the oxidative folding of proteins in the endoplasmic reticulum ${ }^{[66]}$. Riboflavin can also exert an antioxidant action through being a component of the glutathione redox cycle ${ }^{[67]}$.

Furthermore, the current findings revealed that riboflavin administration led to preservation of the proliferative cells of gastric mucosa as indicated in the immunohistochemical results of this work, where this indicated a normal cellular proliferation that maintained the integrity of gastric mucosa. In accordance with this finding, previous studies suggested that riboflavin might act as an anti-proliferative agent in cancer cells by arresting the cell cycle ${ }^{[68]}$. Previous epidemiological studies have reported that riboflavin deficiency led to different mucosal disorders, which were linked to an increased risk of gastric cancer, where riboflavin is involved in the essential oxidation-reduction reactions ${ }^{[69,70]}$.

According to the above discussed findings of the present study, it could be concluded that tartrazine treatment of rats caused significant gastric mucosal structural changes. These structural changes could be alleviated to some extent by ceasing tartrazine treatment. However, a combined recovery of tartrazine along with riboflavin was more efficient in the retrieval of a healthy gastric mucosa, this could be owing to its antioxidant and anti-inflammatory properties. More safety evaluation studies of tartrazine should be done and more strict regulations should be imposed on its use. Riboflavin is beneficial during the recovery period from coloring agents, the routine use of its rich food products can efficiently counteracts these negative effects and maintains the health of our stomach.

\section{CONFLICTS OF INTEREST}

The authors have no conflicts of interest to declare.

\section{REFERENCES}

1. Weglarz-Tomczak, E, Goreck, L. Azo dyesbiological activity and synthetic strategy. Chemik. 2012; 66 (12):1298-307.

2. Nayak, $\mathrm{H}$ and Nath, KG. Dietary Intake of Synthetic Colours by School Children, Karnataka J Agric Sci. 2007, 20 (4): 819-822.

3. Mittal, A, Kurup, L, Mittal, J. Freundlich and Langmuir adsorption isotherms and kinetics for the removal of Tartrazine from aqueous solutions using hen feathers. J Hazard Mater. 2007; 146(1-2):243-248.

4. Liu, R, Chiu, HM, Shiau, CS, Yeh, RL, Hung, YT. Degradation and sludge production of textile dyes by Fenton and photo processes. Dyes Pig. 2007;73:1e6.

5. Tsai, CF, Kuo, CH, Shih, DYC. Determination of 20 synthetic dyes in chili powders and syruppreserved fruits by liquid chromatography/tandem mass spectrometry. J Food Drug Anal. 2015; 23(3): 453-462.

6. Mehedi, N, Mokrane, N, Alami, O, Ainad-Tabet, S, Zaoui, C, Kheroua, O, Saidi, D. A thirteen week ad libitum administration toxicity study of tartrazine in Swiss mice. African Journal of Biotechnology. 2013; 12(28):4519-4529.

7. Amin, KA, Abdel Hameid, H, Abd Elsttar, AH. Effect of food azo dyes tartrazine and carmoisine on biochemical parameters related to renal, hepatic function and oxidative stress biomarkers in young male rats. Food and Chemical Toxicology. 2010; 48(10):2994-2999.

8. Walton, K, Walker, R, van de Sandt, JJ, Castell, JV, Knapp, AG, Kozianowski, G, Roberfroid, M, Schilter, B. The application of in vitro data in the derivation of the acceptable daily intake of food additives. Food Chem Toxicol. 1999; 37 (12): 1175-1197.

9. Turkoglu, S. 2007. Genotoxicity of five food preservatives tested on root tips of Allium cepa L. Mutation Research. 626(1-2): 4-14. 
10. Rao, P, Bhat, RV, Sudershan, RV and Krishna, TP. Consumption of synthetic food colours during festivals in Hyderabad, India, British Food Journal. 2006; 107(5): 276-284.

11. Bhatia, MS. Allergy to tartrazine in psychotropic drugs. Journal of Clinical Psychiatry. 2000; 61(7): 473-476.

12. McCann, D, Barrett, A, Cooper, A, Crumpler, D, Dalen, L, Grimshaw, K. Kitchin, E, Lok, K, Porteous, L, Prince, E, Sonuga-Barke, E, Warner, JO, Stevenson, J. Food additives and hyperactive behaviour in 3-year old and 8/9-year-old children in the community: a randomised, double-blinded, placebo controlled trial. The Lancet 2007; 370(9598): 1560-1567.

13. Ram, FS and Ardern, KD. Tartrazine exclusion for allergic asthma. Cochrane Database of Systematic Reviews. 2001; 4: CD000460.

14. Guendouz, M, Mehedi, N, Zaoui, C, Saidi, $\mathrm{D}$ and Khéroua, O. Immune response after tartrazine subchronic ingestion in Swiss albino mice. International Journal of Pharmacy and Pharmaceutical Sciences. 2013; 5(2): 584-592.

15. Mpountoukas P, Pantazaki A, Kostareli E, Christodoulou P, Kareli D, Poliliou S. Mourelatos, C, Lambropoulou, V, Lialiaris, T. Cytogenetic evaluation and DNA interaction studies of the food colorants amaranth, erythrosine and tartrazine. Food and Chemical Toxicology 2010; 48(10): 2934-2944.

16. Oliveira, GA, Ferraz, ER, Chequer, FM, Grando, MD, Angeli, JP, Tsuboy, MS. Marcarini, JC, Mantovani, MS, Osugi, ME, Lizier, TM, Zanoni, MV, Oliveira, DP. Chlorination treatment of aqueous samples reduces, but does not eliminate, the mutagenic effect of the azo dyes Disperse Red 1, Disperse Red 13 and Disperse Orange 1. Mutation Research. 2010; 703(2): 200-208.

17. Powers, JH. Riboflavin (vitamin B-2) and health, Review Article. Am J Clin Nutr. 2003; 77 (6): 1352-1360.

18. Gaul, C, Diener, HC, Danesch, U; Migravent ${ }^{\circledR}$ Study Group. Improvement of migraine symptoms with a proprietary supplement containing riboflavin, magnesium and Q10: a randomized, placebo-controlled, double-blind, multicenter trial. J Headache Pain. 2015; 16: 516.

19. Bell, IR, Edman, JS, Morrow, FD, Marby, DW, Perrone, G, Kayne, HL, Greenwald, M, Cole, JO. Brief communication. Vitamin B1, B2, and B6 augmentation of tricyclic antidepressant treatment in geriatric depression with cognitive dysfunction. J Am Coll Nutr. 1992; 11(2):159-63.
20. Makdoumi, K, Mortensen, J, Sorkhabi, O, Malmvall, BE, Crafoord, S. UVA-riboflavin photochemical therapy of bacterial keratitis: a pilot study. Graefes Arch Clin Exp Ophthalmol. 2012; 250 (1):95-102.

21. Dai, Z and Koh, WP. B-Vitamins and Bone Health-A Review of the Current Evidence. Nutrients 2015; 7(5): 3322-3346.

22. Cheung, IM, McGhee, CN, Sherwin, T. Beneficial effect of the antioxidant riboflavin on gene expression of extracellular matrix elements, antioxidants and oxidases in keratoconic stromal cells. Clin Exp Optom. 2014; 97(4):349-355.

23. Agnieszka, I, Natorska, J, Wypasek, E, Kołaczkowska, E, Płytycz, B. Experimental immunologyAnti-inflammatory effects of riboflavin and morphine on zymosan-induced peritonitis in Swiss mice. Centr Eur J Immunol. 2008; 33 (3): 98-101.

24. Naghashpour, M, Amani, R, Sarkaki, A, Ghadiri, A, Samarbafzadeh, A, Jafarirad, S, Malehi, AS. Brain-derived neurotrophic and immunologic factors: beneficial effects of riboflavin on motor disability in murine model of multiple sclerosis. Iran J Basic Med Sci. 2016; 19(4):439-448.

25. Tavares, NR, Moreira, PA, Amaral, TF. Riboflavin supplementation and biomarkers of cardiovascular disease in the elderly. J Nutr Health Aging. 2009; 13(5):441-446.

26. Sanches, SC, Ramalho, LN, Mendes-Braz, M, Terra, VA, Cecchini, R, Augusto, MJ, Ramalho, FS. Riboflavin (vitamin B-2) reduces hepatocellular injury following liver ischaemia and reperfusion in mice. Food Chem Toxicol. 2014; 67:65-71.

27. Marashly, ET and Bohlega, SA. Riboflavin has neuroprotective potential: Focus on Parkinson's disease and migraine. Front Neurol. 2017; 8:333.

28. Zschäbitz, S, Cheng, TY, Neuhouser, ML, Zheng, Y, Ray, RM, Miller, JW, Song, X, Maneval, DR, Beresford, SA, Lane, D, Shikany, JM, Ulrich, CM. B vitamin intakes and incidence of colorectal cancer: results from the Women's Health Initiative Observational Study cohort. Am J Clin Nutr. 2013;97 (2):332-343.

29. Webster, RP, Gawde, MD, Bhattacharya, RK. Modulation of carcinogen induced DNA damage and repair enzyme activity by dietary riboflavin. Cancer Lett. 1996; 98: 129-135.

30. Al-Harbi, NO, Imam, F, Nadeem, A, Al-Harbi, MM, Iqbal, M, Ahmad, SF. Carbon tetrachlorideinduced hepatotoxicity in rat is reversed by treatment with riboflavin. Int Immunopharmacol. 2014; 21 (2):383-388. 
31. Ali, FA, Abdelgayed, SAS, EL-Tawil, SO, Bakeer, MA. Toxicological and Histopathological Studies on the Effect of Tartrazine in Male Albino Rats. International Journal of Biological, Biomolecular, Agricultural, Food and Biotechnological Engineering. 2016; 10(8): 513-518.

32. Gaertner, DJ, Hallman, TM, Hankenson, FC, Batchelder, MA. Anesthesia and analgesia for laboratory rodents. In: Fish, R.E., Danneman, P.J., Brown, M., Karas, A.Z. (Eds.), Anesthesia and Analgesia in Laboratory Animals. , 2nd ed. Academic Press, London (UK). 2008; pp. 239-297.

33. Gamble, M. The hematoxylins and eosin. In: Theory and Practice of Histological Techniques. Editors; Bancroft, JD and Gamble, M. 6th ed. Philadelphia: Churchill Livingstone: Elsevier; 2008; pp 121-134.

34. Jones, ML, Bancroft, JD, Gamble, M. Connective tissues and stains. In: Theory and Practice of Histological Techniques. Editors; Bancroft, JD and Gamble, M. 6th ed. Philadelphia: Churchill Livingstone: Elsevier; 2008; pp 135-160.

35. Buchwalow,IB,Böcker,W.Immunohistochemistry: Basics and Methods. Springer, Heidelberg, Dordecht, London, New York. 2010; pp. 31-39.

36. Bozzola, JJ, Russell, LD. Electron Microscopy Principles and Techniques for Biologists. 2nd ed. Toronto, London: Jones and Bartlett Publishers; 1999; p. 16.

37. Dawson-Saunders, B, Trapp, R. Basic and Clinical Biostatistics. third ed. Lange Medical Book/ McGraw-Hill Medical Publishing Division. 2001; p. $161-218$.

38. Khayyat, L, Essawy, A, Sorour, J, Soffar, A. Tartrazine induces structural and functional aberrations and genotoxic effects in vivo. Peer J. 2017; 5: e3041.

39. Meyer, SK, Probert, PME, Lakey, AF, Axon, AR, Leitch, AC, Williams, FM Jowsey, PA, Blain, PG, Kass, GEN, Wright, MC. Hepatic effects of tartrazine (E 102) after systemic exposure are independent of oestrogen receptor interactions in the mouse. Toxicol Lett. 2017; 273: 55-68.

40. Tanaka, T, Takahashi, O, Oishi, S and Ogata, A. Effects of tartrazine on exploratory behaviour in a three-generation toxicity study in mice. Reproductive Toxicology 2008; 26(2): 156-163.

41. Sarkar, R and Ghosh, AA. Metanil yellow - an azo dye induced histopathological and ultruasrtctrual changes in albino rat (Rattus norvegicus), Int.Q.J. Life Sci. 2012; 7 (1): 427 - 432.
42. Al-Seeni, MN, El Rabey, HA, Al-Hamed, AM, Zamazami, MA. Nigella sativa oil protects against tartrazine toxicity in male rats. Toxicol Rep. 2017; 5: 146-155.

43. Poul, M, Jarry, G, Elhkim, MO and Poul, JM. Lack of genetoxic effect of food dyes amaranth, sunset yellow and tartrazine and their metabolites in the gut micronucleus assay in mice. Food and Chemical Toxicology 2009; 47(2): 443-448.

44. Oluwole, FS and Iyortim, MI. Monosodium Glutamate, a possible Threat to Gastric Integrity in Rats. J Biol Sci 2006; 6 (4): 671- 674.

45. Himri, I, Bellahcen, S, Souna, F, Belmakki, F, Aziz, M, Bnouham, M, Zoheir, J, Berkia, Z, Aziz, M, Saalaoui, E. A 90-day oral toxicity study of tartrazine, a synthetic food dye, in wistar rats. Int J Pharm Pharm Sci. 2011; 3 (3): 159-169.

46. Saxena, B and Sharma, S. Food Color Induced Hepatotoxicity in Swiss Albino Rats, Rattus norvegicus. Toxicol Int. 2015; 22(1):152-7.

47. Raju, D, Ilango, K, Chitra, V, Ashish, K. Evaluation of Anti-ulcer activity of methanolic extract of Terminalia chebula fruits in experimental rats. $\mathrm{J}$ Pharm Sci and Res. 2009; 1(3):101-107.

48. Sasaki, YUF, Kawaguchi, S, Kamaya, A, Ohshita, M, Kabasawa, K, Iwama, K, Taniguchi, K, Tsuda, $\mathrm{S}$. The comet assay with 8 mouse organs: results with 39 currently used food additives. Mutat Res. 2002; 519: 103-119.

49. Feng, J, Cerniglia, CE and Chen, H. Toxicological significance of azo dye metabolism by human intestinal microbiota. Frontiers in Bioscience Journal. 2012; 4(4): 568-586.

50. Demirkol, O, Zhang, X, Ercal, N. Oxidative effects of Tartrazine (CAS No 1934-21-0) and New Coccin .CAS No. 2611-82-7) azo dyes on CHO cells. J. Verbr. Lebensm. 2012; 7:229-236.

51. Siraki, G, Chan, TS, Galati, G, Teng, S, O’Brien, PJ. N-oxidation of aromatic amines by intracellular oxidases. Drug Metab Rev. 2002; 34: 549-564.

52. Stuehr, DJ. Enzymes of the L-arginine to nitric oxide pathway. J Nutr. 2004; 134 (10 Suppl): 2748-2751.

53. Castañeda, AA, Denning, JW, Chang, L, Mercer, DW. Does upregulation of inducible nitric oxide synthase (iNOS) render the stomach more susceptible to damage? J Surg Res. 1999; 84(2):174-179.

54. Kochar, NI, Chandewal, AV, Bakal, RL and Kochar, PN. Nitric Oxide and the Gastrointestinal Tract. International Journal of Pharmacology. 2011; 7: 31-39. 
55. Peresleni, T, Noiri, E, Bahou, W, Goligorsky, M. Anti-senseoligodeoxynucleotidesto inducible NO synthase rescue epithelial cells from oxidative stress injury. American Journal of Physiology. 1996; 270(6):971-977.

56. Rus, C, Gherman, V, Miclaus, A, Mihalca, G, Nadas, C. Comparative toxicity of food dyes on liver and kidney in guinea pigs: A histopathological study. Annals of RSCB. 2010; 15: 161-165.

57. Moutinho, IL, Bertges, LC, Assis, RV. Prolonged use of the food dye tartrazine (FD and $\mathrm{C}$ yellow no 5 ) and its effects on the gastric mucosa of Wistar rats. Braz J Biol. 2007; 67(1):141-5.

58. Yamazaki, Y, Ueda, T, Kohli, Y, Fujiki, N, Imamura, Y, Fukuda, M. Importance of acidic mucin secretions by foveolar and mucous neck cells of rat fundic mucosa as the defence mechanisms against $\mathrm{HCl}$ as revealed by fasting. Eur J Histochem. 1992; 36(2):161-176.

59. Gong, DH, Turner, B, Bhaskar, KR, Lamont, JT. Lipid binding to gastric mucin: protective effect against oxygen radicals Am J Physiol. 1990; 259: 681-686.

60. Suzuki, H, Nishizawa, T, Tsugawa, H, Mogami, S, Hibi, T. Roles of oxidative stress in stomach disorders. J Clin Biochem Nutr. 2012; 50(1): 35-39.

61. Bologna-Molina, R, Mosqueda-Taylor, A, MolinaFrechero, N, Mori-Estevez, AD, Sánchez-Acuña, G. Comparison of the value of PCNA and Ki-67 as markers of cell proliferation in ameloblastic tumors. Med Oral Patol Oral Cir Bucal 2013; 18: 174-179.

62. Hoffmann, W. Regeneration of the gastric mucosa and its glands from stem cells Curr Med Chem. 2008; 15(29):3133-3144.

63. Martin, GR and Wallace, JL. Gastrointestinal inflammation: a central component of mucosal defense and repair. Exp Biol Med. 2006; 231: 130-137.

64. Bertollo, CM, Oliveira, AC, Rocha, LT, Costa, KA, Nascimento, EB Jr, Coelho, MM. Characterization of the antinociceptive and anti-inflammatory activities of riboflavin in different experimental models. Eur J Pharmacol. 2006; 547(1-3):184-91.

65. Qureshi, AA, Tan, X, Reis, JC, Badr, MZ, Papasian, CJ, Morrison, DC, Qureshi, N. Suppression of nitric oxide induction and pro-inflammatory cytokines by novel proteasome inhibitors in various experimental models. Lipids Health Dis. 2011; 10: 177.

66. Tu, BP, Ho-Schleyer, SC, Travers, KJ, Weissman, JS. Biochemical basis of oxidative protein folding in the endoplasmic reticulum. Science. 2000; 290: 1571-1574.

67. Ashoori, M and Saedisomeolia, A. Riboflavin (vitamin B2) and oxidative stress: a review. Br J Nutr. 2014; 111(11):1985-1891.

68. de Souza Queiroz, KC, Zambuzzi, WF, Santos de Souza, AC, da Silva, RA, Machado, D, Justo, GZ, Carvalho, HF, Peppelenbosch, MP, Ferreira, CV. A possible anti-proliferative and anti-metastatic effect of irradiated riboflavin in solid tumours. Cancer Lett. 2007; 258(1):126-134.

69. Manthey, KC, Chew, YC, Zempleni, J. Riboflavin deficiency impairs oxidative folding and secretion of apolipoprotein B-100 in HepG2 cells, triggering stress response systems. J Nutr. 2005; 135: 978982.

70. Matnuri, M, Zheng, C, Sidik, D, Bai, G, Abdukerim, M, Abdukadier, A Ahmat, K, Ma, Y, Eli, M. Correlation analysis of riboflavin, RFT2 and Helicobater pylori in gastric carcinoma. Int $\mathrm{J}$ Clin Exp Pathol. 2015; 8(10):13339-13345. 
الملخص العربى - ابى

\section{تأثثير تارترازين على الغثاء المخاطى للمعدة والدور المحتمل للتعافى مع أو بدون ريبوفلافين في ذكر الجرذ الأبيض البالغ الغئغ}

ولاء محمد علوان ومروة عوض عبد الحميا إبراهيم

قسم الهستولوجياو بيولوجيا الخلية ـ كلية الطب - جامعة طنطا

مقدمة: تارترازين هو أحد أصباغ الآزو التي تعتبر أكثر ألوان الأطعمة الإصطناعية شيوعًا والتي تستخدم على نطاق و اسع في العديد من المنتجات الغذائية. يستخدم تارترازين في العديد من البلدان النامية بدون لو ائح صارمة. الهُف من العمل: هو در اسة تأثثر تارترازين على الغشاء المخاطى للمعدة وتقييم الدور المحتمل للتعافى بعد سحبها مع أو بدون ريبوفلافين في الجرذان.

مواد و طرق البحث: تم تقسيم أربعة و عشرين من ذكور الجرذان البيضاء البالغة بالتساوي إلى 4 مجمو عات؛ الضابطة، رييوفلافين، مجموعة العلاج بتارترازين (أعطيت تارترازين عن طريق الفم 200 مجم / كجم / يوم لمدة 60 يومًا)، مجمو عة التعافى من تارنر ازين (أعطيث تارترازين عن طريق الفم 200 مجم / كجم / يوم لمدة 60 يومًا ثم تترك دون علاج لمدة 60 يومًا أخرى) مجمو عة التعافى من تارثر ازين مع ريبوفلافين (أعطيت تارتر ازين لمدة 60 يومًا ثم أوققت و أتبعت بريبو فلافين لمدة 60 يومًا أخرى). تم تجهيز عينات المعدة الغُدية للتقنيات الهستولوجية و الهسنوكميائية المناعية. النتائج: أظهرت المجموعة المعالجة بتارترازين درجات متفاوتة من الأضر ار للغشاء المخاطى مع إنخفاض كبير في سمكه. أظهرت الخلايا الجداريّة تفرغ فى السيتوبلازم و أنوية غير منتظمة، و أظهرت الخلايا الرئيسة كذلك تفرغ فى

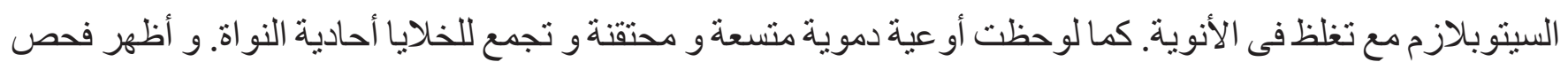
التركيب الدقيق وجود خلايا جداريّة و رئيسة ذات أنوية متكنفة و توسع فى الشبكة الإندوبلازمية الخشنة. وأظهرت مجمو عة التعافى من تارتر ازين أن الغشاء المخاطى للمعدة سليم تقريبًا. بينما أظهرت مجمو عة التعافى من تارترازين

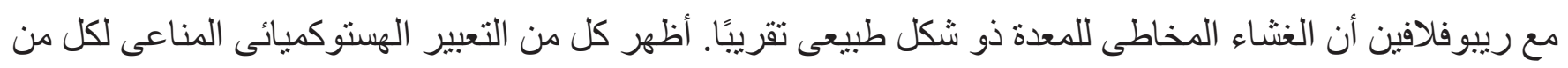
iNOS Ki67 زيادة ذات دلالة إحصائية مقترنة بإنخفاض في تفاعل صبغة شيف الحمضية، إلا أن مجموعة التعافى رئى من تارتر ازين أظهرت إختلافات ذات دلالة إحصائية في هذه العو امل مقارنة بالمجمو عة الضابطة، في حين أظهرت مجمو عة التعافى من تارنر ازين مع ريبوفلافين إختلافات غير ذات دلالة إحصائية مع المجموعة الضابطة. الاستنتاج: إن تارثرازين قد أثز على المعدة وتم تخفيف أثره عن طريق إيقافه. كان التعافى مع ريبوفلافين أكثر كفاءة في تعافى الغثاء المخاطى للمعدة. 